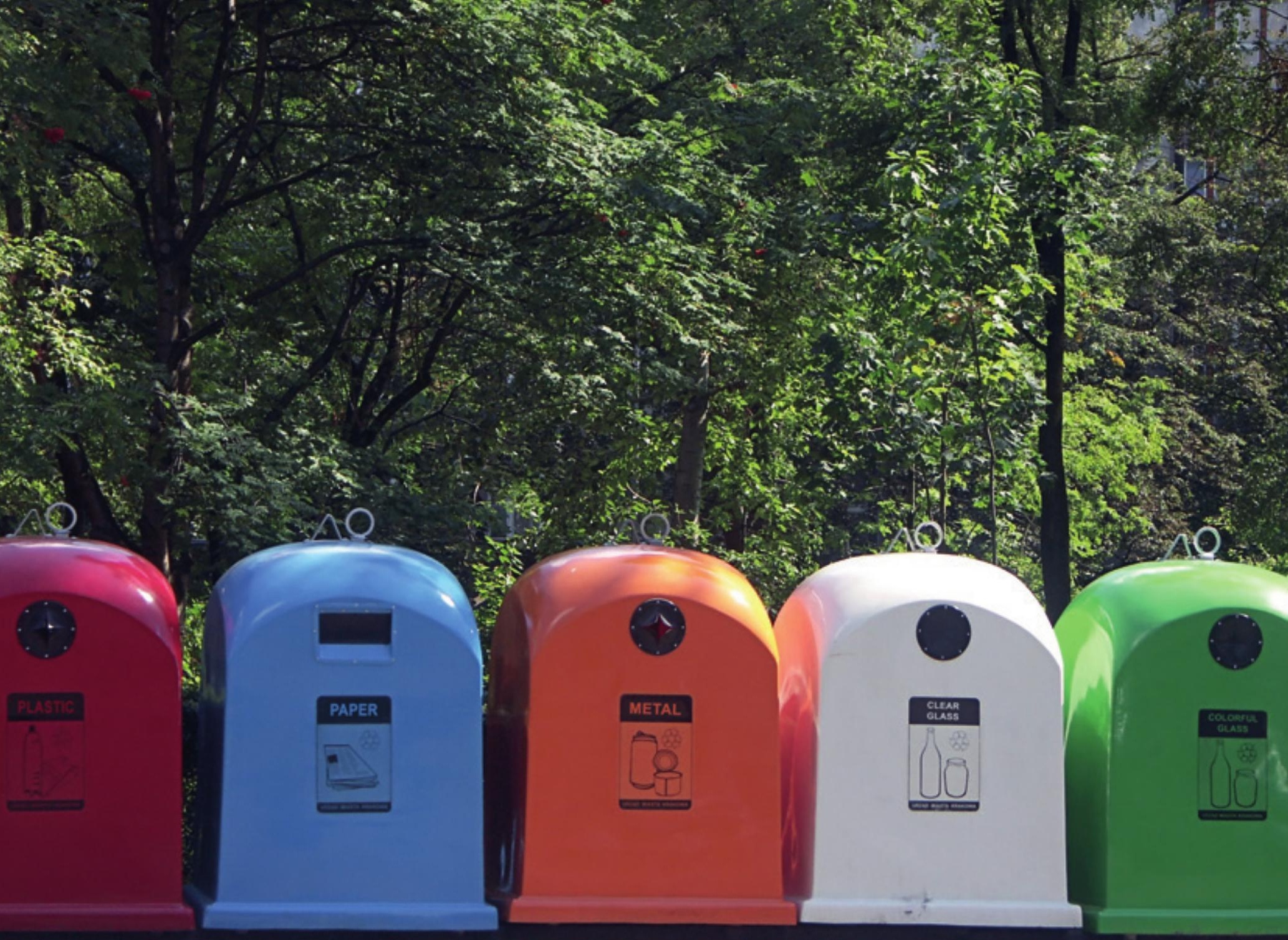





\section{Verkenning effect verschuiven meetpunt recycling verpakkingen}


Versie: definitief

Reviewer: W. Post

Goedgekeurd door: A. v.d. Bent

Opdrachtgever: het Ministerie van Infrastructuur en Waterstaat

Financier: het Ministerie van Infrastructuur en Waterstaat

Dit rapport is gratis te downloaden op https://doi.org/10.18174/503911/ of op www.wur.nl/wfbr (onder publicaties).

(C) 2019 Wageningen Food \& Biobased Research, instituut binnen de rechtspersoon Stichting Wageningen Research.

Het is de opdrachtgever toegestaan dit rapport integraal openbaar te maken en ter inzage te geven aan derden. Zonder voorafgaande schriftelijke toestemming van Wageningen Food \& Biobased Research is het niet toegestaan:

a. dit door Wageningen Food \& Biobased Research uitgebrachte rapport gedeeltelijk te publiceren of op andere wijze gedeeltelijk openbaar te maken;

b. dit door Wageningen Food \& Biobased Research uitgebrachte rapport, c.q. de naam van het rapport of Wageningen Food \& Biobased Research, geheel of gedeeltelijk te doen gebruiken ten behoeve van het instellen van claims, voor het voeren van gerechtelijke procedures, voor reclame of antireclame en ten behoeve van werving in meer algemene zin;

c. de naam van Wageningen Food \& Biobased Research te gebruiken in andere zin dan als auteur van dit rapport.

Postbus 17, 6700 AA Wageningen, T 03174800 84, E info.wfbr@wur.nl, www.wur.nl/wfbr. Wageningen Food \& Biobased Research is onderdeel van Wageningen University en Research.

Alle rechten voorbehouden. Niets uit deze uitgave mag worden verveelvoudigd, opgeslagen in een geautomatiseerd gegevensbestand of openbaar gemaakt in enige vorm of op enige wijze, hetzij elektronisch, hetzij mechanisch, door fotokopieën, opnamen of enige andere manier, zonder voorafgaande schriftelijke toestemming van de uitgever. De uitgever aanvaardt geen aansprakelijkheid voor eventuele fouten of onvolkomenheden. 


\section{Inhoud}

Samenvatting $\quad 4$

$\begin{array}{lr}\text { Summary } & 6\end{array}$

$\begin{array}{llr}\text { 1. Inleiding } & 8\end{array}$

$\begin{array}{lr}\text { 2. Methoden } & 9\end{array}$

2.1 Huidige berekeningswijze van het recyclingpercentage $\quad 11$

2.2 Relevante artikelen uit het nieuwe uitvoeringsbesluit $\quad 13$

3. Recyclingpercentage voor verpakkingen gemaakt van papier en karton 17

$\begin{array}{ll}3.1 \text { Huidige berekeningswijze } & 19\end{array}$

3.2 Nieuwe berekeningswijze $\quad 19$

$\begin{array}{lr}3.3 \text { Aanvullende opmerking } & 19\end{array}$

4. Recyclingpercentage voor glazen verpakkingen $\quad 20$

$\begin{array}{ll}4.1 \text { Huidige berekeningswijze } & 23\end{array}$

4.2 Nieuwe berekeningswijze $\quad 23$

$\begin{array}{ll}4.3 \text { Aanbeveling } & 24\end{array}$

5. Verkenning van de berekening van het recyclingpercentage voor metalen verpakkingen

5.1 Huidige berekeningswijze $\quad 26$

5.2 Benodigde gegevens voor het berekenen van het nieuwe recyclingpercentage $\quad 27$

$\begin{array}{ll}5.2 .1 \text { Oud-metaalhandel } & 27\end{array}$

$\begin{array}{ll}5.2 .2 \text { Klein chemisch afval } & 27\end{array}$

5.2.3 Gescheiden ingezamelde metaalverpakkingen $\quad 27$

5.2.4 Bodemas-verwerking van afvalverbrandingsinstallaties $\quad 28$

$\begin{array}{ll}\text { 5.2.4.1 Bodemas-route Ferrometalen } & 28\end{array}$

$\begin{array}{ll}\text { 5.2.4.2 Bodemas-route non-ferrometalen } & 29\end{array}$

$\begin{array}{ll}\text { 5.2.5 PMD route metalen } & 29\end{array}$

5.2.6 Nascheiding-route metalen $\quad 30$

5.3 Berekening van nieuwe recyclingpercentages voor metaalverpakkingen 30

6. Algemene opmerkingen over de recycling van houten verpakkingen 33

$\begin{array}{ll}\text { 7. Overall recyclingpercentage } & 34\end{array}$

$\begin{array}{lr}\text { Literatuur } & 35\end{array}$ 


\section{Samenvatting}

EU richtlijn 94/62/EG beschrijft welke doelstellingen moeten worden bereikt door de lidstaten met betrekking tot het terugwinnen en recyclen van verpakkingsafval. De richtlijn voor het bepalen van dit recyclingpercentage wordt gewijzigd. Deze wijziging is beschreven in EU richtlijn 2018/852 en verder uitgewerkt in uitvoeringsbesluit EU 2019/665. Door deze wijziging verschuift het meetmoment in de recyclingketen voor de bepaling van de hoeveelheid gerecycled verpakkingsafval. In de huidige regelgeving varieert de methode van het bepalen van het recyclingpercentage met het materiaal en terugwinnings- of recyclingmethode. Het nieuwe uitvoeringsbesluit streeft er zoveel mogelijk naar om het recyclingpercentage vast te stellen op basis van het gewicht aan verpakkingsmateriaal dat een recyclingproces wordt ingebracht. Doorgaans komt dit er op neer dat het meetmoment hierdoor verschuift naar later in de recyclingketen. Het nieuwe uitvoeringsbesluit heeft dus invloed op de door Nederland gerapporteerde recyclingpercentages voor de verschillende verpakkingsmaterialen. In opdracht van het Ministerie Infrastructuur en Waterstaat heeft Wageningen Food \& Biobased Research onderzocht wat de effecten zijn van het nieuwe uitvoeringsbesluit EU 2019/665 op de door Nederland gerapporteerde recyclingpercentages van verpakkingen van papier \& karton, glas en metaal. In een voorafgaand rapport was dit al uitgevoerd voor kunststof verpakkingen. De benodigde veranderingen in de monitoringswijze zijn geen onderdeel van het onderzoek.

Het recyclingpercentage wordt bepaald op basis van de onderstaande vergelijking. Waarbij het recycling-massarendement $\left(R_{m}\right)$ wordt berekend op basis van het gewicht aan Nederlands verpakkingsmateriaal dat het recyclingproces wordt in gebracht ( $M_{\text {recycling}}$ ) en het gewicht op de Nederlandse markt gebrachte verpakkingen ( $M_{\text {markt }}$ ).

$$
R_{m}=\frac{M_{\text {recycling }}}{M_{\text {markt }}}
$$

\section{Berekeningswijze van het recyclingpercentage}

De hoeveelheid op de markt gebrachte verpakkingen verandert niet met de nieuwe berekeningswijze. De hoeveelheid verpakkingen die het recyclingproces worden ingebracht zal echter wel anders worden. Als gevolg van de nieuwe wetgeving, zal later in de recyclingketen gemeten worden, waardoor verliezen die optreden bij sorteren en voorbereiden tot recyclen nu niet meer meegenomen kunnen worden in het te rapporteren gewicht verpakkingen die het recyclingproces worden ingebracht. In dezelfde situatie zal het te rapporteren recyclingpercentage dus dalen. Het meetpunt verschuift dus naar later in de recyclingketen, zoals weergegeven in de figuur hieronder.

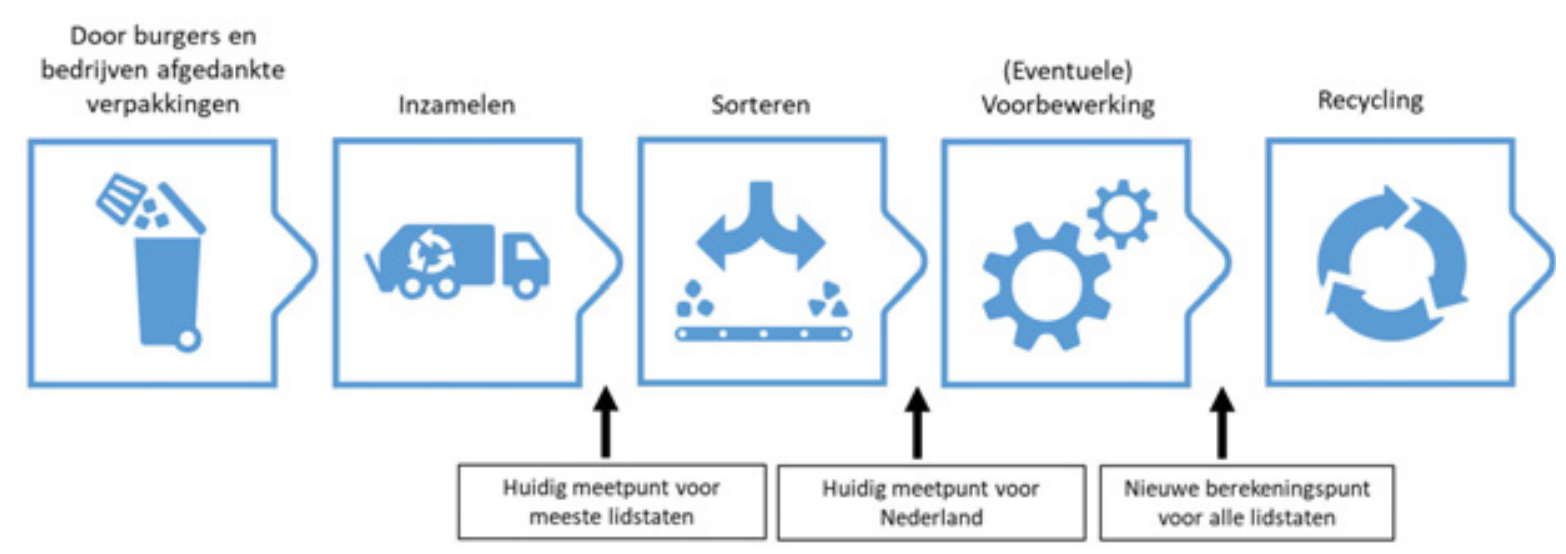

Schematische weergave van recyclingketens voor verpakkingsmateriaal en de verschuiving van het meetpunt naar het nieuw voorgestelde berekeningspunt voor het recyclingpercentage volgens het nieuwe uitvoeringsbes/uit. 


\section{Papier en karton}

In 2017 werd in Nederland 1262 kton aan verpakkingen gemaakt van papier en karton op de markt gebracht. Na gebruik werd het overgrote deel van de papier en kartonnen verpakkingen gescheiden ingezameld en een klein deel teruggewonnen door nascheiding (dit betreft drankenkartons). De hoeveelheid oud-papier en karton dat door papier recyclingbedrijven is geregistreerd als gebruikte grondstof is de grondslag voor de berekening van de hoeveelheid teruggewonnen papier en kartonverpakkingen. Deze hoeveelheid bedroeg 1095 kton na correctie voor vochtopname en internationale handel in oud-papier in 2017.. Hiermee voldoet de huidige rekenwijze voor het recyclingpercentage van papier en kartonverpakkingen al aan de eisen die gesteld zijn in EU 2019/665 en zal het recyclingpercentage volgens de nieuwe rekenregels gelijk zijn aan die Nederland al hanteerde voor 2017, namelijk $87 \%$.

\section{Glas}

In 2017 werd in Nederland 500 kton aan glazen verpakkingen op de markt gebracht. Hiervan werd 420 kton bruto gescheiden ingezameld en 10 kton teruggewonnen door nascheiding als IBC bouwstof ${ }^{1}$. Volgens de huidige rekenregels was het recyclingpercentage daarmee $86 \%$. Voor het berekenen van het recyclingpercentage volgens de nieuwe rekenregels moet de concentratie verpakkingsglas in de glasproducten bekend zijn. Hiermee kan worden berekend dat de hoeveelheid gerecycled verpakkingsglas volgens de nieuwe rekenregels 380 kton bedraagt. Dit komt overeen met een recyclingpercentage van $76 \%$. In het geval in de toekomst deze interpretatie strenger wordt gedaan en IBC bouwstof en verwerken van verpakkingsglas in bakstenen niet meer als recycling gelden, dan daalt het recyclingpercentage naar $71 \%$. Uitgaande van de gerapporteerde $86 \%$ in 2017 kent het effect van de nieuwe meetmethode daardoor de volgende spreiding: tussen $71 \%$ en $76 \%$. Met een meer ruimhartige interpretatie zou KSP-uitstoot mogelijk meegeteld kunnen worden en zou het recyclingpercentage nog kunnen stijgen tot $82 \%$.

\section{Metalen}

In 2017 werd in Nederland 216 kton metalen verpakkingen op de markt gebracht. Deze verpakkingen werden op verschillende wijzen teruggewonnen: via de oud-metaal handel, via gescheiden inzameling van klein chemisch afval (KCA), via gescheiden inzameling bij bedrijven en milieustraten, via bodemassen van afvalverbrandingsinstallaties, via gescheiden inzameling van PMD en via nascheiding. Het gewicht aan gerecyclede metaal-verpakkingen is door het Afvalfonds Verpakkingen berekend op 205 kton en op basis daarvan heeft men een recyclingpercentage van 95\% vastgesteld volgens de heersende rekenregels. Voor de berekening van het recyclingpercentage volgens de nieuwe rekenregels is een volledige uitsplitsing noodzakelijk over de genoemde zeven inzamel of terugwinningsketens en is er veel detailinformatie nodig van de hoeveelheden die in die ketens rond gaan alsmede van de samenstelling van deze stromen. Deze detailinformatie ontbreekt momenteel, zodat het onmogelijk is om een recyclingpercentage voor metalen verpakkingen te berekenen volgens de nieuwe rekenregels. Wel kan worden ingeschat dat dit recyclingpercentage hoog zal zijn op basis van de relatief grote gewichten aan teruggewonnen metalen uit de bodemassen van afvalverbrandingsinstallaties en de grote hoeveelheid logistieke hulpmiddelen die nagenoeg compleet zullen worden ingezameld en gerecycled.

Samenvattend, de recyclingpercentages voor verpakkingen zullen dalen ten gevolge van de nieuwe rekenregels. In dit rapport zijn berekeningen van deze recyclingpercentages in 2017 voor papier \& kartonnen verpakkingen en glazen verpakkingen gepresenteerd. Samen met berekeningen voor kunststofverpakkingen uit een eerder rapport en de ruwe veronderstelling dat de recyclingpercentages voor hout en metaal constant blijven, levert dat een daling in het overall recyclingpercentage op van $78 \%$ (volgens de oude rekenregels) naar $74-75 \%$ (volgens de nieuwe rekenregels) voor verpakkingen in Nederland in 2017. Overigens is het waarschijnlijk dat de recyclingpercentages voor beide materialen die nu niet kunnen worden berekend wel iets dalen, zodat het overall-recyclingpercentage nog ongeveer $1 \%$ lager zal uitpakken.

\footnotetext{
${ }^{1}$ IBC-bouwstoffen zijn niet-vormgegeven bouwstoffen die alleen mogen worden toegepast met isolatie-, beheers- en controle- (IBC) maatregelen, omdat het toepassen zonder deze maatregelen anders leidt tot teveel emissies naar het milieu.
} 


\section{Summary}

EU directive 94/62/EU describes the targets that member states need to attain in relation to the recycling and recovery of packaging waste. This directive is altered with respect to the calculation method of recycling rates. This alteration is described in the new, amended directive EU 2018/852 and further elaborated in an implementation decision EU 2019/665. This change in legislation implies that the measurement point for recycling is shifted. Under the current legislation the method to calculate the recycling rate varies with the material and the recycling or recovery methods. The new implementation decision aims to determine the recycling rate with the weights of packaging waste that are introduced in a recycling operation, to the extent that this is possible. For most materials this implies that the measurement point is shifted further in the chain towards recycling. The new implementation decision therefore influences the recycling rates that the Netherlands reports for the various packaging materials. The Dutch ministry of Infrastructure and Water management commissioned Wageningen Food \& Biobased Research to study the effects of the new implementation decision EU 2019/665 on the recycling rates reported by the Netherlands for paper \& board, glass and metal. Previously, these effects had already been studied for plastic packaging. The implications for the monitoring methods were out of scope.

The recycling rate is determined with the equation below. The recycling rate $\left(R_{m}\right)$ is calculated with the mass of Dutch packaging materials that is fed into a recycling operation $\left(M_{\text {recycling }}\right.$ ) divided by the weight of packages placed on the Dutch market ( $\left.M_{\text {market }}\right)$.

$$
R_{m}=\frac{M_{\text {recycling }}}{M_{\text {market }}}
$$

\section{Calculation method for the recycling rate}

The amount of packaging placed on the Dutch market will not change with the new calculation point. Whereas, the amount of packages recycled will alter as a consequence of the new calculation point. As a consequence of the new calculation methodology, in which sorting and preparation-for-recycling losses are now excluded from the recycled mass of packaging materials, the new mass of packaging materials fed into a recycling operation will be lower than the previously reported mass of recycled packaging materials. Under the same conditions, the reported recycling rate will decrease. The calculation point is shifted towards the recycling in the collection \& recycling chain, as depicted below.

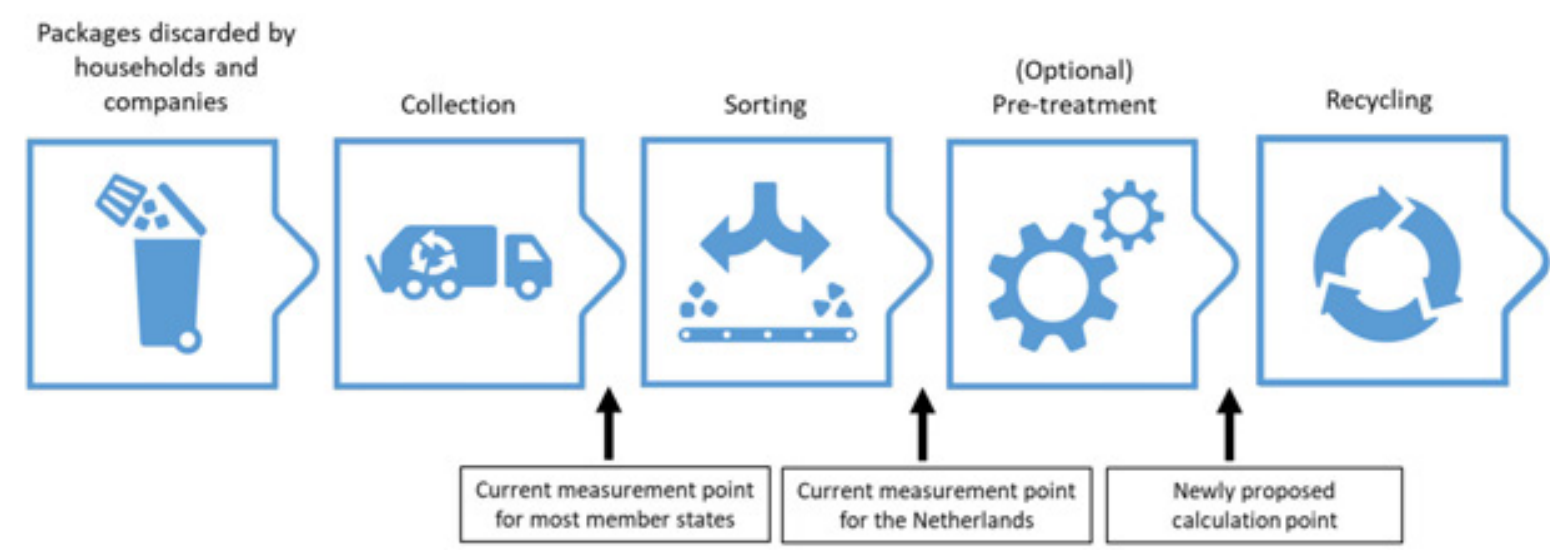

Schematic representation of collection \& recycling chains for packaging materials and the shift in the calculation point according to the new implementation decision. 
Paper and board

In 2017, 1262 kton of paper \& board packages were placed on the Dutch market. After use these were predominantly discarded into separate collection bins and only a minor part was mechanically recovered from mixed municipal solid waste (MSW). This recovered amount relates to beverage cartons. The total amount of retrieved paper \& board material that was used and registered by the recycling companies as feedstock was used to calculate the total amount of retrieved paper and board packages. This total amount equalled 1095 kton for 2017 after corrections for absorbed moisture and international trade were conducted. This implies that the current Dutch calculation method for the recycling rate of paper and board packages is already compliant with EU 2019/665. Therefore, the recycling rate according to the new calculation point will equal the previous reported recycling rate of $87 \%$.

\section{Glass}

In 2017,500 kton of glass packages were placed on the Dutch market. Roughly 420 kton gross glass packaging waste was separately collected and $10 \mathrm{kton}$ was mechanically recovered as construction material. According to the current calculation method the recycling rate was $86 \%$. According to the new calculation point, the various glass products made by sorting have to be distinguished and corrected for the concentration packaging glass they contain. Hence, according to the new calculation point, the amount of Dutch packaging glass fed into a recycling operation was $380 \mathrm{kton}$. This corresponds to a recycling rate of $76 \%$. In case the interpretation will be more strict and construction materials and use of packaging glass in bricks cannot be considered as recycling, the recycling rate will decrease to $71 \%$. Considering a reported rate of $86 \%$ in 2017 , the effect of the new measuring point will result in a recycling rate between $71 \%$ and $76 \%$. A more "flexible" interpretation would lead to taking glass-rejects into account as well, resulting in a possible increase in recycling rate to $82 \%$.

\section{Metals}

In 2017, 216 kton of metal packages were placed on the Dutch market. These packages were retrieved in various ways: via the salvage businesses and metal-trade, household chemical waste, separate collection at companies and municipal recycling centres, bottom ash treatment of waste incineration facilities, separate collection of lightweight packaging wastes and mechanical recovery from MSW. Afvalfonds Verpakkingen calculated the weight of recycled metal packages to be 205 kton in 2017 and hence a recycling rate of 95\% was reported according to the current calculation method. For the new calculation method of the recycling rate a complete description of all seven metal recycling and recovery chains is required, which involves the amounts of materials and their compositions. This detailed information is currently lacking, which impairs the calculation of the recycling rate according to the new methodology. Nevertheless, as a crude estimation this recycling rate will be relative high, since relatively large weights of metals have been recovered from incinerator bottom ashes and large amounts of metal secondary packages are used and are hence likely to be collected and recycled almost completely.

The new calculation methodology which stems from the implementation decision will lower the recycling rates for the packaging materials, in comparison to the rates which have previously been determined according to the current calculation method. In this report the newly calculated recycling rates for Dutch paper \& board and glass packages in 2017 are presented. Together with the previously reported new recycling rates for plastic packages and the crude assumption that the recycling rates for wood and metal packages will remain constant, this renders a reduction in the overall recycling rate for Dutch packaging materials in 2017 from 78\% (according to the current calculation method) to 74 to $75 \%$ (according to the new calculation method). Since it is likely that the recycling rates for both materials that cannot be calculated at the moment will drop slightly as well, the overall recycling rate for packaging materials will actually be about $1 \%$ lower. 


\section{Inleiding}

Dit project is uitgevoerd in opdracht van het Ministerie van Infrastructuur en Waterstaat (IenW), tevens financier. Aanleiding voor het onderzoek is de nieuwe EU richtlijn 2018/852, welke verder is uitgewerkt in het uitvoeringsbesluit EU 2019/665. Deze richtlijn en het besluit geven aan dat de Europese commissie van plan is om het meetmoment in de recyclingketen voor verpakkingen te verplaatsen. Wageningen Food \& Biobased Research (WFBR) heeft al in een eerder rapport de vraag beantwoord wat het verwachte effect is van het verschuiven van het meetmoment op het recyclingpercentage van kunststofverpakkingen [Brouwer et al., 2019]. In reactie op dit rapport heeft het Ministerie IenW de vraag gesteld aan WFBR of zij ook inzicht kunnen geven in de effecten van het verschuiven van het meetmoment op recyclingpercentage van andere verpakkingsmaterialen. In gezamenlijk overleg is toen besloten om houten verpakkingen niet in detail te onderzoeken, wel zullen er enkele algemene kenmerken van deze keten worden geschetst. Concreet stelde het Ministerie IenW de volgende vragen:

1. Het recyclingpercentage van alle verpakkingen is nu $78 \%$, welk percentage is te verwachten met de nieuwe meetmethode?

2. Het recyclingpercentage van glas is nu $86 \%$, welk percentage is te verwachten met de nieuwe meetmethode?

3. Het recyclingpercentage van oud papier en karton is nu circa $87 \%$, welk percentage is te verwachten met de nieuwe meetmethode?

4. Welk aanvullend onderzoek is nodig om het recyclingpercentage voor aluminium en Ferrometalen afzonderlijk te kunnen bepalen?

Deze studie verkent het effect van de nieuwe rekenwijze op de recyclingpercentages van verpakkingsmaterialen voor Nederland in 2017.

De monitoringswijze van deze percentages valt buiten de scope van dit onderzoek. Deze studie is uitgevoerd door onderzoekers van WFBR in opdracht van het Ministerie IenW. De onderzoekers hebben een objectief en onafhankelijk onderzoek uitgevoerd om de onderzoeksvragen te beantwoorden. Tijdens het onderzoek is contact geweest met de materiaalorganisaties, Afvalfonds Verpakkingen en Rijkswaterstaat om onze inschattingen te toetsen. De feedback van deze partijen is door de onderzoekers beoordeeld en waar nodig verwerkt in dit rapport.

Dit rapport is in eerste instantie bedoeld voor de opdrachtgever, het Ministerie van IenW. De definitieve versie van dit rapport zal openbaar gemaakt worden, waarna het beschikbaar zal zijn voor alle geïnteresseerden. 


\section{Methoden}

EU richtlijn 94/62/EG regelt het beheer van verpakkingen en verpakkingsafval, met als doel dit te harmoniseren. "Deze richtlijn heeft tot doel de nationale maatregelen betreffende het beheer van verpakking en verpakkingsafval te harmoniseren, enerzijds om elk effect daarvan op het milieu van de Lid-Staten en derde landen te voorkomen of te beperken en aldus een hoog milieubeschermingsniveau te waarborgen, en anderzijds om de werking van de interne markt te garanderen en handelsbelemmeringen, concurrentieverstoring en concurrentiebeperking in de Gemeenschap te voorkomen" [Richtlijn 94/62/EG]. In artikel 6 van deze richtlijn staat beschreven welke doelstellingen moeten worden bereikt door de lidstaten $\mathrm{m}$.b.t. de terugwinning en recycling van verpakkingsafval. In beschikking 2005/270/EG is de berekeningswijze van recyclingpercentages van verpakkingsmaterialen beschreven [Beschikking 2005/270/EG].

In de kaderrichtlijn afvalstoffen worden de definities gegeven van de begrippen 'recycling' en 'nuttige toepassing [Richtlijn 2008/98/EG]. Deze worden hieronder gegeven:

Artikel 3.15: "Nuttige toepassing": Elke handeling met als voornaamste resultaat dat afvalstoffen een nuttig doel dienen door hetzij in de betrokken installatie, hetzij in de ruimere economie andere materialen te vervangen die anders voor een specifieke functie zouden zijn gebruikt, of waardoor de afvalstof voor die functie wordt klaargemaakt.

Artikel 3.17: "Recycling": Elke nuttige toepassing waardoor afvalstoffen opnieuw worden bewerkt tot producten, materialen of stoffen, voor het oorspronkelijke doel of voor een ander doel. Dit omvat het opnieuw bewerken van organisch afval, maar het omvat niet energieterugwinning, noch het opnieuw bewerken tot materialen die bestemd zijn om te worden gebruikt als brandstof of als opvulmateriaal.

De richtlijn voor het bepalen van dit recyclingpercentage wordt gewijzigd, deze wijziging is beschreven in EU richtlijn 2018/852 en in uitvoeringsbesluit EU 2019/665. Door deze wijziging verschuift het meetmoment in de recyclingketen voor de bepaling van de hoeveelheid gerecyclede verpakkingsmaterialen en dit zal dus effect hebben op de door Nederland gerapporteerde recyclingpercentages voor de verschillende verpakkingsmaterialen.

Het recyclingpercentage wordt bepaald op basis van Vergelijking 1 . Waarbij het recyclingpercentage $\left(R_{m}\right)$ wordt berekend op basis van het gewicht gerecycled verpakkingsmateriaal $\left(M_{\text {gerecycled }}\right)$ en het gewicht op de markt gebracht verpakkingsmateriaal $\left(M_{\text {markt }}\right)$.

$$
R_{m}=\frac{M_{\text {gerecycled }}}{M_{\text {markt }}}
$$

\section{Vergelijking 1: Berekening van het recyclingpercentage.}

De hoeveelheid op de markt gebracht verpakkingsmateriaal $\left(M_{\text {markt }}\right)$ zal niet veranderen door de nieuwe richtlijn ${ }^{2}$. Wel verschuift de locatie in de keten waarop de hoeveelheid gerecycled verpakkingsmateriaal wordt bepaald; het berekeningspunt verschilt in meestal van het oude meetpunt. Dit is verduidelijkt in tabel 1 voor de verschillende verpakkingsmaterialen.

Formeel wordt $R_{m}$ in de Nederlandse taal als recyclingpercentage aangeduid, omdat het de materiaalopbrengst beschrijft over meerdere processtappen (inzamelen, sorteren en recyclen). Dit wordt ook wel aangeduid met het begrip ketenrendement.

2 Deze hoeveelheid kan in principe veranderen door de wijze waarop herbruikbare verpakkingen moeten worden geregistreerd en verrekend. De hiervoor benodigde detailgegevens zijn echter niet openbaar beschikbaar, zodat er vanuit is gegaan dat deze hoeveelheid constant blijt. 
Tabel 1 Meetpunten en berekeningspunten per soort verpakkingsmateriaal.

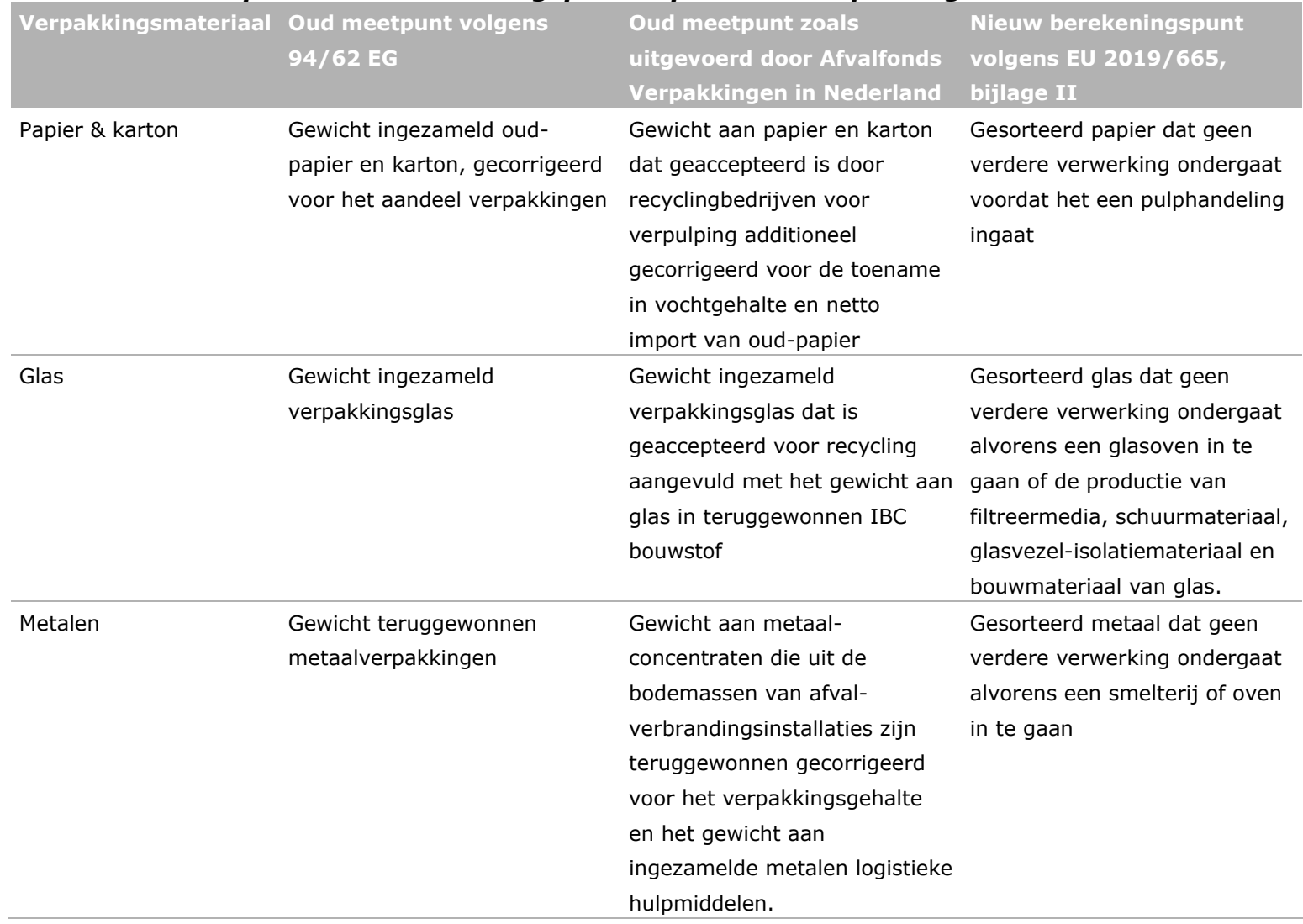

Kortom, het nieuwe berekeningspunt verschilt van het oude meetpunt. Omdat de uitvoeringswijze van het meetpunt nu nog verschilt per lidstaat, zal het effect van de nieuwe berekeningswijze ook verschillen per lidstaat. Dat is afgebeeld in figuur 1.

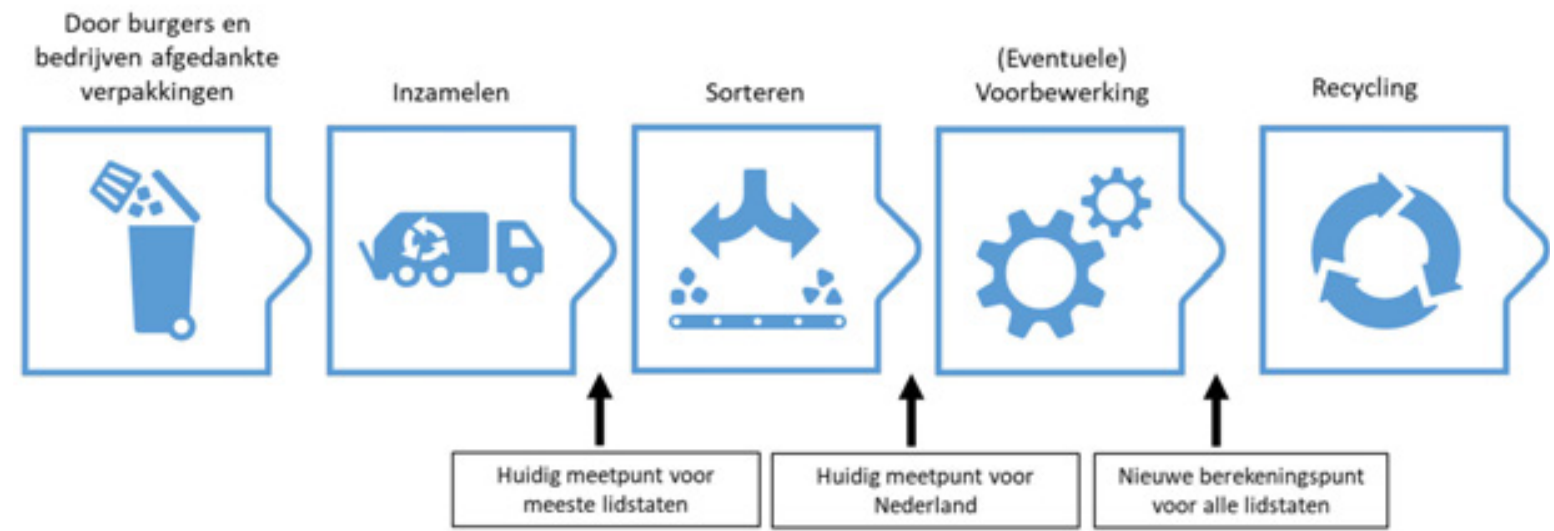

Figuur 1: Schematische weergave van recyclingketens voor verpakkingsmateriaal en de verschuiving van het meetpunt naar het nieuw voorgestelde berekeningspunt voor het recyclingpercentage volgens de nieuwe richtlijn.

De huidige Nederlandse berekeningssystematiek is formeel vastgesteld in de regeling formulier verslaglegging verpakkingen [Regeling 2014] en dit is verder uitgewerkt in het Uitvoerings- en monitoringprotocol verpakkingen. Voor de vijf verschillende verpakkingsmaterialen zijn gedetailleerde monitoringsprotocollen opgesteld. Dit document is opgesteld door Stichting Nedvang en de Vereniging Nederlandse gemeenten (VNG) onder verantwoordelijkheid van de begeleidingscommissie Raamovereenkomst [UMP]. Jaarlijks publiceert Afvalfonds Verpakkingen monitoringsrapportages aangaande de recycling van verpakkingen in Nederland. De kwaliteit van deze rapportages wordt vervolgens door de onafhankelijke commissie toezicht monitoring verpakkingen getoetst. 


\subsection{Huidige berekeningswijze van het recyclingpercentage}

In de huidige, Nederlandse berekeningswijze voor het recyclingpercentage wordt doorgaans de hoeveelheid gerecycled materiaal bepaald op basis van de hoeveelheid gesorteerd product, waar afhankelijk van het soort materiaal nog enkele correcties op worden verricht. De aard van de correcties verschilt per materiaalsoort en wordt hieronder dan ook per materiaal toegelicht [UMP] ${ }^{3}$.

\section{Oud-papier \& karton}

In Nederland gaat een deel van het ingezamelde oud-papier en karton direct naar het recyclingbedrijf (verpulper). Een ander (variërend) deel van het ingezamelde oud-papier en karton wordt eerst gesorteerd in een sorteerbedrijf alvorens het aan het recyclingbedrijf (verpulper) verhandeld wordt. De hoeveelheid oud-papier en karton die aan recyclers wordt aangeboden en geaccepteerd wordt voor recycling wordt officieel geregistreerd als het gerecycled gewicht. Dit is dus de som van beide stromen, zowel ingezameld en direct verhandeld als ingezameld, gesorteerd en verhandeld. Verder neemt het oud-papier \& karton netto vocht op tijdens gebruik en inzameling, zodoende werd in 2017 het gerecyclede gewicht oud-papier \& karton met een factor 4,2\% verminderd. Tenslotte is er een levendige handel in oud-papier en karton tussen de lidstaten en heeft Nederland een bovengemiddeld grote verwerkingscapaciteit, hetgeen resulteert in een netto-importstroom van oudpapier \& karton. Ook hiervoor wordt gecorrigeerd door het Afvalfonds Verpakkingen.

\section{Verpakkingsglas}

Het overgrote deel van de hoeveelheid gerecycled verpakkingsglas bestaat uit gescheiden ingezameld verpakkingsglas door gemeenten bij burgers en door bedrijven. Aangezien jaarlijks onderzoek aantoont dat het vervuilingspercentage onder de 2,5\% ligt (zowel ten aanzien van vreemd-materialen als glazen niet-verpakkingen), wordt dit ingezamelde gewicht nu ongecorrigeerd gebruikt.

Een relatief klein deel van de hoeveelheid gerapporteerd gerecycled verpakkingsglas wordt door middel van nascheiding teruggewonnen uit het gemengde huishoudelijke restafval. Deze nascheiding vindt bij een beperkt aantal nascheidingsinstallaties plaats. Hier wordt inert materiaal verwijderd uit de organisch natte fractie. Dit inert product bestaat uit zand, glasscherven, kiezels, steen, etc. en wordt na reiniging verhandeld als IBC bouwstof. De hoeveelheid op deze wijze gerecycled verpakkingsglas wordt berekend uit het aandeel verpakkingsglas in deze teruggewonnen bouwstof vermenigvuldigd met het totaalgewicht aan teruggewonnen bouwstof.

\section{Metalen verpakkingen}

In Nederland wordt het gerapporteerde gerecyclede gewicht aan metaalverpakkingen berekend met een rekenmodel. Een beschrijving van dit rekenmodel, inclusief de negen kernveronderstellingen is te vinden het monitoringsprotocol voor metalen verpakkingen [UMP]. Hierin worden de volgende bijdragen meegenomen:

- $\quad$ het teruggewonnen gewicht aan metaalverpakkingen uit de bodemassen van afvalverbrandingsinstallaties,

- $\quad$ het teruggewonnen gewicht aan metaalverpakkingen middels nascheiding uit restafval,

- het gescheiden ingezamelde gewicht aan metaalverpakkingen bij bedrijven,

- het gescheiden ingezamelde gewicht aan metaalverpakkingen door gemeenten,

- het gescheiden ingezamelde gewicht aan metaalverpakkingen binnen het Klein Chemisch Afval (KCA) en

- de hoeveelheid ingezamelde metalen logistieke hulpmiddelen.

Dit rekenmodel is in stappen ontwikkeld. De eerste versie werd door RWS leefomgeving (toen nog SenterNovem genaamd) en Stichting Kringloop Blik ontwikkeld. Nedvang en later Afvalfonds Verpakkingen hebben dit model overgenomen en verder uitgewerkt. De Inspectie Leefomgeving en Transport heeft in haar inspectierapport van 2017 dit gecontroleerd en had hierover geen inhoudelijke opmerkingen, wel enkele algemene aanbevelingen [ILT 2017].

\footnotetext{
${ }^{3}$ Additionele uitleg rond de verrichte correcties werden verkregen van Coen Bertens van Afvalfonds Verpakkingen.
} 
Eén van de kernveronderstellingen is dat alle metaalverpakkingen die niet gescheiden worden ingezameld of worden nagescheiden, in te verbranden afvalstromen belanden (huishoudelijk restafval, bedrijfsmatig restafval, gemeentelijk veegafval en restafval uit openbare prullenbakken). Hieruit kan worden opgemaakt dat dit rekenmodel de hoeveelheid metaalverpakkingen in de invoer van afvalverbrandingsinstallaties berekent uit het verschil tussen de op de markt gebrachte metaalverpakkingen en de gescheiden ingezamelde plus nagescheiden metaalverpakkingen. Deze gewichten worden vervolgens vermenigvuldigd met onafhankelijk vastgestelde terugwinningsrendementen voor metaalverpakkingen voor afvalverbranding met bodemas-opwerking. Het gewicht aan ingezamelde metalen logistieke hulpmiddelen (gasflessen, drums, IBC-rekken, glasbokken, rolcontainers, etc.) wordt sinds de ILT controle met een $1 \%$ verlies voor onverhoopte inzamelverliezen gebruikt.

De gewichten aan metaalverpakkingen die uit het gescheiden ingezameld PMD worden teruggewonnen, worden in Nederland niet separaat meegenomen bij de berekening van het huidige recyclingpercentage. Verondersteld wordt namelijk dat deze metalen verbrand en teruggewonnen worden. Ook de gewichten aan metaalverpakkingscomponenten (sluitingen en deksels) die via de gescheiden inzameling van verpakkingsglas worden teruggewonnen, worden niet meegerekend. 


\subsection{Relevante artikelen uit het nieuwe uitvoeringsbesluit}

De belangrijkste artikelen van het nieuwe uitvoeringsbesluit [2019/665/EU] worden hieronder genoemd en besproken, alvorens er in de komende hoofdstukken een interpretatie van deze artikelen voor de verschillende verpakkingsmaterialen zal volgen.

In artikel 1.1.3b: De definitie van het nieuwe berekeningspunt.

Om te berekenen of de in artikel 6, lid 1, onder a) tot en met e), van Richtlijn 94/62/EG vastgestelde doelstellingen zijn verwezenlijkt is het gewicht van teruggewonnen of gerecycleerd verpakkingsafval gelijk aan de input van verpakkingsafval bij een effectief proces van terugwinning of recycling. Indien de output van de sorteerinstallatie zonder significante verliezen naar effectieve recycling- of terugwinningsprocessen wordt gestuurd, is het aanvaardbaar om deze output als het gewicht van het teruggewonnen of gerecycleerd verpakkingsafval te beschouwen.

In artikel 1.7.6 quater.1.a volgt hierover een verdere verduidelijking

De hoeveelheid gerecycleerd verpakkingsafval is de hoeveelheid afval bij het rekenpunt. In de hoeveelheid afval die de recyclingshandeling binnenkomt, zijn doelmaterialen begrepen. Dit afval mag alleen nietdoelmateriaal omvatten voor zover de aanwezigheid hiervan bij de specifieke recyclingshandeling is toegestaan. De rekenpunten die van toepassing zijn op bepaalde afvalmaterialen en bepaalde recyclinghandelingen zijn gespecificeerd in bijlage II.

Hierbij is de definitie van het begrip "doelmaterialen" en "niet-doelmaterialen" belangrijk. Deze definities staan in Artikel 1.2a en b

1.2.a "doelmaterialen: verpakkingsafvalmateriaal dat in een gegeven recyclinghandeling opnieuw wordt bewerkt tot producten, materialen of stoffen die geen afval zijn;

b "niet-doelmaterialen": afvalmateriaal dat niet in een gegeven recyclinghandeling opnieuw wordt bewerkt tot producten, materialen of stoffen die geen afval zijn(...)

In artikel 1.7.6 quater.1.a wordt gesteld dat niet-doelmaterialen alleen mogen worden meegeteld bij het gerecyclede gewicht voor zo ver hun aanwezigheid is toegestaan. Dit impliceert dus dat verontreinigingen die aanwezig zijn in het gesorteerde product, niet van het gerecyclede gewicht hoeven te worden afgetrokken, zolang hun aanwezigheid is toegestaan.

Artikel 1.7.6 quater.1.b stelt dat door een recyclingbedrijf geweigerde sorteerproducten niet mogen worden meegeteld bij het gerecyclede gewicht.

Indien het meetpunt betrekking heeft op de output van een installatie die zonder verdere voorbehandeling afval voor recycling verstuurt, of betrekking heeft op de input van een installatie waar het afval zonder verdere voorbehandeling wordt ingebracht, wordt de hoeveelheid gesorteerd afval die door de recyclinginrichting wordt afgewezen, niet meegerekend in de hoeveelheid gerecycleerd afval.

Artikelen $1.4 \mathrm{a}, \mathrm{b}$ : Benodigde correcties ten gevolge van internationale handel

a. Om te berekenen of de in artikel 6, lid 1, onder a) tot en met e), van Richtlijn 94/62/EG vastgestelde doelstellingen zijn verwezenlijkt, wordt verpakkingsafval dat uit de Unie wordt uitgevoerd alleen als teruggewonnen of gerecycleerd meegeteld als er degelijk bewijs is dat de terugwinning en/of recycling hebben plaatsgevonden onder omstandigheden die in grote lijnen gelijkwaardig zijn aan die welke in de toepasselijke wetgeving van de Unie zijn voorgeschreven.

b. Om te berekenen of de in artikel 6, lid 1, onder a) tot en met e), van Richtlijn 94/62/EG vastgestelde doelstellingen zijn verwezenlijkt, wordt verpakkingsafval dat in een andere lidstaat of buiten de Unie is geproduceerd en voor terugwinning of recycling naar een lidstaat is gestuurd, niet meegeteld als teruggewonnen of gerecycleerd in de lidstaat waarnaar dit verpakkingsafval is verzonden.

In artikel 1.7.6 quater.1.g volgt een verdere verduidelijking 
Wanneer verpakkingsafval dat in een bepaalde lidstaat is geproduceerd vóór het meet- of het rekenpunt is vermengd met ander afval of met afval uit een ander land, wordt het aandeel van het uit de desbetreffende lidstaat afkomstig verpakkingsafval bepaald met gebruikmaking van passende methoden, zoals elektronische registers en steekproefonderzoek. Indien dergelijke afvalstoffen een verdere voorbehandeling ondergaan, wordt de hoeveelheid niet-doelmaterialen die door die behandeling worden verwijderd in mindering gebracht, rekening houdend met de verhouding en, waar van toepassing, de kwaliteit van de afvalstoffen uit verpakkingsafval uit een bepaalde lidstaat.

Artikel 1.5a: benodigde correctie voor het vochtgehalte

Om te berekenen of de in artikel 6, lid 1, onder a) tot en met e), van Richtlijn 94/62/EG vastgestelde doelstellingen zijn verwezenlijkt, wordt het gewicht van het teruggewonnen of gerecycleerd verpakkingsafval gemeten gebruikmakend van een natuurlijke vochtigheidsgraad van het verpakkingsafval die vergelijkbaar is met de vochtigheidsgraad van de gelijkwaardige op de markt gebrachte verpakking.

In artikel 1.7.6 quater.1.e volgt een verdere verduidelijking

Indien de vochtigheidsgraad van het verpakkingsafval in het meetpunt afwijkt van die van de verpakking die in de handel is gebracht, wordt het gewicht van de verpakking op het meetpunt gecorrigeerd om overeen te komen met de vochtigheidsgraad van vergelijkbaar, in de handel gebracht verpakkingsafval.

Artikel 1.5b: benodigde correctie voor niet-verpakkingen

Om te berekenen of de in artikel 6, lid 1, onder a) tot en met e), van Richtlijn 94/62/EG vastgestelde doelstellingen zijn verwezenlijkt, wordt, voor zover dit uitvoerbaar is, het gewicht van niet-

verpakkingsmateriaal dat samen met het verpakkingsafval is opgehaald, niet meegeteld.

In artikel 1.7.6 quater.1.f volgt een verdere verduidelijking.

Materiaal dat niet afkomstig is van verpakkingen, zoals afval van hetzelfde materiaal dat samen met het verpakkingsafval is ingezameld en residuen van producten die zich in de gebruikte verpakking bevonden, mag niet meegerekend worden bij de hoeveelheid gerecycleerd verpakkingsafval.

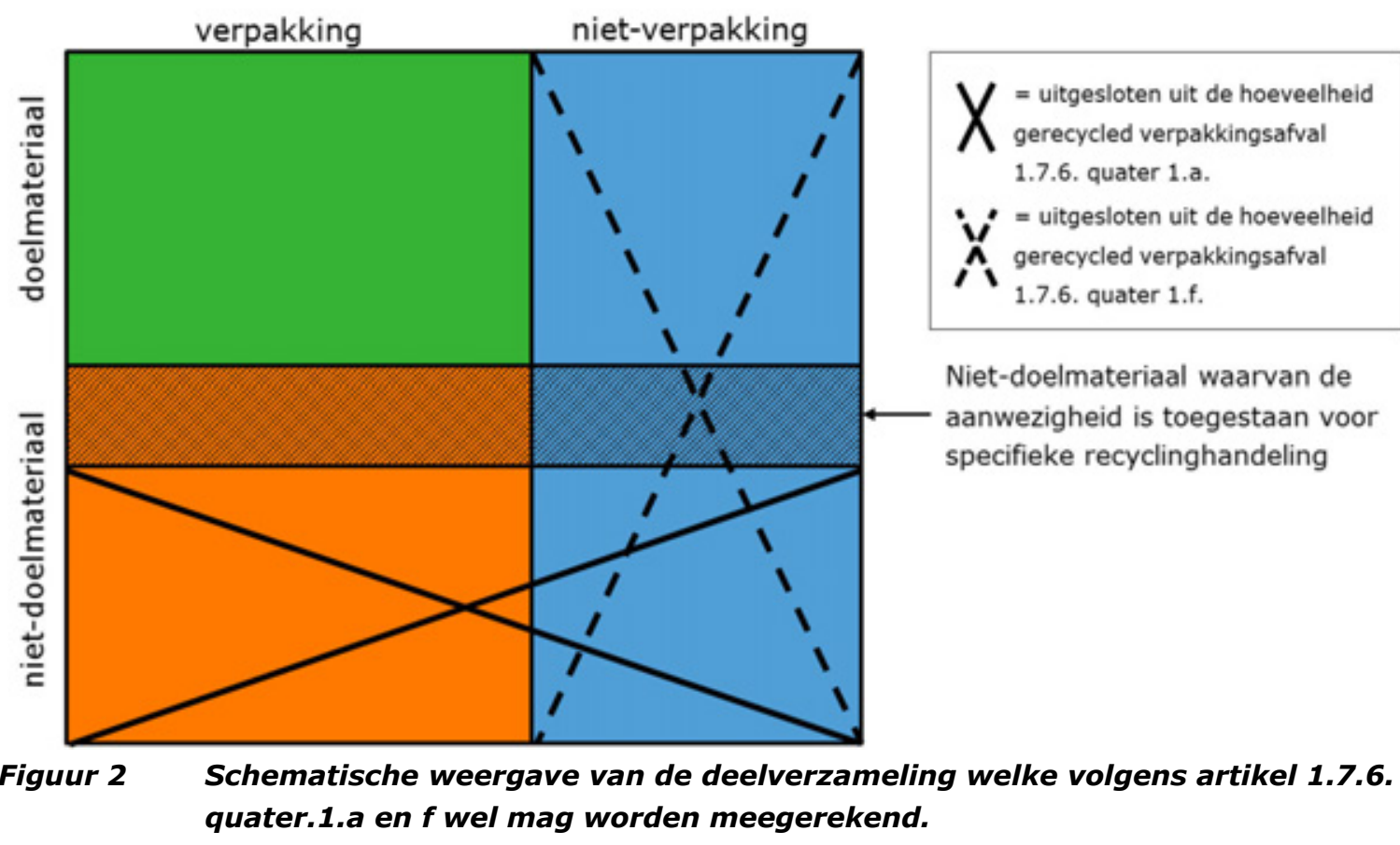


Omdat deze teksten ingewikkeld zijn en aanleiding kunnen geven tot misverstanden, wordt er in figuur 2 een schematische verduidelijking van de bedoelde uitsluitingen gegeven. Ingezameld en/of gesorteerd verpakkingsafval bestaat doorgaans uit de volgende soorten objecten:

- Beoogde verpakkingen, hier weergegeven in het groen als verpakkingen uit doelmateriaal,

- Niet-beoogde verpakkingen, hier getoond in het oranje als verpakkingen uit nietdoelmateriaal,

- Niet-verpakkingen, hier getoond in het blauw. Dit is een brede categorie, die dus zowel huishoudelijke objecten, auto-onderdelen, constructiemateriaal, speelgoed, als ook restmaterialen (organisch afval, textiel, etc.) bevat. Soms wordt er nog onderscheid gemaakt tussen niet-verpakkingen die wel van het beoogde materiaal zijn en niet-verpakkingen die van een ander, niet-beoogd materiaal zijn. In het kader van EU 2019/665 worden echter alle nietverpakkingen uitgesloten. Overigens, in sommige documenten worden niet-doelmaterialen ook wel "productvreemde vervuiling" genoemd, vaak heeft dit betrekking op nietverpakkingen.

Een deel van de niet-beoogde verpakkingen mogen wel meegerekend worden met het recyclingpercentage, dit is het oranje gearceerde gebied in figuur 2 . Zowel ingezameld materiaal als gesorteerd verpakkingsafval bevatten namelijk niet-doelmaterialen, vaak stoorstoffen genaamd. De maximaal toelaatbare gehaltes van deze stoorstoffen zijn vastgelegd in acceptatievoorwaarden voor ingezameld materiaal en specificaties voor gesorteerd verpakkingsafval. Deze stoorstoffen zijn niet beoogd, dus een niet-doelmateriaal maar mogen tot zekere gehaltes wel in de verpakkingsafvalstromen aanwezig zijn. Deze hoeveelheid aan stoorstoffen die volgens de specificaties wel aanwezig mogen zijn, worden niet uitgesloten volgens EU 2019/665 en mogen dus wel meegerekend worden. Dit is weergegeven in figuur 2 als het oranje gearceerde gebied.

De technische werkelijkheid van verpakkingsafval is echter nog ingewikkelder, omdat beoogde verpakkingen niet alleen bestaan uit beoogde materialen maar ook uit niet-beoogde materialen. In sommige gevallen kunnen deze niet-beoogde verpakkingscomponenten niet worden gerecycled, dan spreken we over "product-eigen vervuiling". Bekende voorbeelden zijn de kurk en het label van de wijnfles, nietjes en paperclips bij oud-papier, maar ook productresiduen die in de verpakking zijn ingesloten. Volgens artikel 1.7.6 quater.1.f mogen ingesloten productresiduen dus niet meegerekend worden met het gerecyclede gewicht. Andere product-eigen-vervuilingen mogen soms wel en soms niet meegerekend worden in het gerecyclede gewicht, dit blijkt uit de definities van het meetpunt in bijlage II van EU 2019/665.

In artikel 7.6 quinquies beschrijft hoe er moet worden omgegaan met de recycling van verpakkingsmetalen uit bodemassen van verbrandingsinstallaties.

$1.0 m$ te berekenen of de in artikel 6 , lid 1 , onder $\mathrm{f}$ ) tot en met i), van Richtlijn 94/62/EG vastgestelde doelstellingen zijn verwezenlijkt is de hoeveelheid gerecycleerde metalen die van de AVI-bodemas is gescheiden, gelijk aan de massa van de metalen die zijn gescheiden van de onbewerkte AVI-bodemas afkomstig uit het verpakkingsafval, zonder andere in het metaalconcentraat aanwezige materialen zoals mineraalverbindingen of metalen die niet afkomstig zijn van het verpakkingsafval.

2.Voor de berekening van de massa van de gerecycleerde metalen die gescheiden zijn van de AVI-bodemas passen de lidstaten de rekenmethode van bijlage III toe.

In bijlage III wordt de berekeningswijze voor de recycling van metalen uit bodemassen verder toegelicht. 
BIJLAGE III Methode voor het berekenen van de gerecycleerde metalen die na verbranding van verpakkingsafval zijn gescheiden

1. Voor de formules in deze bijlage gelden de volgende termen:

$\mathrm{m}_{\text {total IBA Fe/Al }}$ totale massa van ferrometalen of aluminium in AVI-bodemas in een bepaald jaar;

$\mathrm{m}_{I B A} \mathrm{Fe} / \mathrm{nFe}$ concentrates massa van het ferro- of het non-ferrometaalconcentraat, gescheiden van de onbewerkte AVI- bodemas in een bepaald jaar;

$\mathrm{C}_{\mathrm{IBA} \mathrm{Fe} / \mathrm{Al}}$ concentratie van ferrometalen of aluminium in het respectieve metaalconcentraat;

mIBA Fe/AI massa aan ferrometalen of aluminium in het ferro- of het non-ferrometaalconcentraat, gescheiden van de AVI-bodemas in een bepaald jaar;

$\mathrm{m}_{\text {non-metallic }}$ massa van niet-metalen bestanddelen in specifieke concentraten van ferrometalen of aluminium;

$r_{A l}$ het aandeel aluminium in de non-ferrometalen in het non-ferrometaalconcentraat dat van de AVI-bodemas is gescheiden;

$\mathrm{M} P W \mathrm{Fe} / \mathrm{Al}$ massa van ferrometalen of aluminium uit verpakkingsafval dat in een bepaald jaar in een verbrandingshandeling wordt ingebracht;

$\mathrm{m}_{W \mathrm{Fe} / \mathrm{Al}}$ massa van alle ferrometalen of aluminium die in een bepaald jaar een verbrandingshandeling binnenkomen; en

MPW IBA Fe/Al massa van de gerecycleerde ferrometalen of aluminium uit verpakkingsafval in een bepaald jaar.

2.Nadat ferro/non-ferroconcentraat is gescheiden van de onbewerkte AVI-bodemas, wordt het ferrometalen/aluminiumgehalte van het metaalconcentraat berekend aan de hand van de volgende formule:

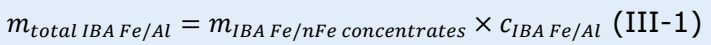

3. De gegevens over de massa van ferro- en non-ferrometaalconcentraten moeten afkomstig zijn van installaties waarin de metaalconcentraten worden gescheiden van onbewerkte AVI-bodemas.

4. De concentratie van ferrometalen en aluminium als gevolg van de verwerking van onbewerkte AVIbodemas wordt berekend aan de hand van gegevens die zijn verzameld door middel van regelmatig onderzoek van installaties waar metaalconcentraten worden behandeld en van installaties waar de metalen die van de AVI- bodemas zijn gescheiden, worden gebruikt voor de productie van metaalproducten, door toepassing van de volgende formules:

a) voor ferrometalen

$$
c_{I B A F e}=\frac{m_{I B A F e}}{m_{I B A F e c o n c e n t r a t e s}}=\frac{m_{I B A F e} \text { concentrates }-m_{\text {non-metallic }}}{m_{I B A F e} \text { concentrates }}(\text { III-2), en }
$$

b) voor aluminium

$$
C_{I B A A l}=\frac{m_{I B A A l}}{m_{I B A} \text { Fe concentrates }}=\frac{\left(m_{I B A n F e} \text { concentrates }-m_{\text {non-metallic }}\right) \times r_{A l}}{m_{I B A \text { A }} \text { concentrates }}(\text { III-3) }
$$

5. De massa van de/het gerecycleerde ferrometalen/aluminium uit verpakkingsafval in alle van de AVIbodemas gescheiden gerecycleerde ferrometalen/aluminium wordt bepaald aan de hand van steekproeven van het afval dat de verbrandingshandeling ingaat. Dit onderzoek wordt ten minste om de vijf jaar gehouden en wanneer er redenen zijn om aan te nemen dat de samenstelling van het verbrande afval ingrijpend is veranderd. De massa van ferrometalen/aluminium uit verpakkingsafval wordt berekend aan de hand van de volgende formule:

$$
m_{P W I B A F e / A l}=\frac{m_{P W F e / A l}}{m_{W F e / A l}} \times m_{\text {total IBA Fe/Al }}(\text { III-4) }
$$




\section{Recyclingpercentage voor verpakkingen gemaakt van papier en karton}

De Nederlandse keten van inzameling, sortering en recycling van oud-papier en karton is redelijk goed beschreven. Naast de gegevens die Afvalfonds Verpakkingen publiceert over deze keten, publiceren ook de Koninklijke Vereniging van Nederlandse Papier en Kartonfabrieken (VNP, www.vnp.nl) en de producentenverantwoordelijkheidsorganisatie voor de niet-verpakkingen van papier en karton (PRN, www.prn.nl) regelmatig kengetallen van de industrie op hun websites. Behalve de hoeveelheden ingezameld oud-papier \& karton en de hoeveelheden gerecycled oud-papier, zijn ook de resultaten van vervuilingsonderzoek van ingezameld oud-papier \& karton openbaar [Hoogland, 2015]. Daar staat tegenover dat de openbare wetenschappelijke literatuur over de materiaalstromen in dit inzamel- en recyclingsysteem beperkt is [Ewijk van, 2018]. Er zijn wel enkele bijdragen geschreven over het sorteren van oud-papier en karton [Bobu et al., 2010; Rahman et al., 2013]. Typerende aspecten van deze keten zijn:

- Omvangrijke materiaalstroom ten opzichte van andere verpakkingsmaterialen,

- Relatief veel bedrijfsmatige verpakkingen van papier \& karton en minder huishoudelijke,

- Relatief veel niet-verpakkingen van papier \& karton, maar de verhouding verpakkingen ten opzichte van niet-verpakkingen neemt wel toe door toenemende digitalisering: meer internetaankopen door consumenten, ontlezing en meer papiervrije administratie.

- Veel internationale handel in ingezameld, gesorteerd en gerecycled papier \& karton,

- De materiaalstroom neemt vocht op tijdens gebruik en inzameling,

- Dynamische markt met veel ontwikkelingen.

- Het gehalte verpakkingen stijgt met de jaren,

- Het ingezamelde oud-papier en karton wordt deels eerst gesorteerd en dan aan recyclingbedrijven verkocht, of direct aan recyclingbedrijven verkocht. Er wordt gesorteerd als de marktprijzen voor gesorteerd papier gunstiger zijn of als het ingezamelde materiaal te vervuild is.

De belangrijkste artikelen van het toepassingsbesluit [2019/665] die van toepassing zijn op de inzamel en recyclingketen van verpakkingen gemaakt van papier en karton, staan in de onderstaande tabel opgesomd. Zie paragraaf 2.2 voor de citaten van deze artikelen. 


\begin{tabular}{|c|c|}
\hline \multicolumn{2}{|c|}{ papier \& karton. } \\
\hline Artikel van het besluit & Consequentie voor de berekeningswijze \\
\hline Bijlage II & $\begin{array}{l}\text { Berekeningspunt is gesorteerd papier dat geen verdere verwerking ondergaat voordat het } \\
\text { een pulphandeling ingaat. Omdat op het huidig meetpunt in Nederland al het gewicht aan } \\
\text { papier \& karton is dat de pulphandeling in gaat wordt bepaald, is er geen aanvullende } \\
\text { correctie nodig }\end{array}$ \\
\hline Artikel $1.4 \mathrm{a}$ & $\begin{array}{l}\text { Geëxporteerd oud-papier mag alleen worden meegeteld als er degelijk bewijs is dat recycling } \\
\text { in het buitenland heeft plaatsgevonden. (Zover ons bekend, gebeurt dit al in de huidige } \\
\text { Nederlandse berekeningswijze) }\end{array}$ \\
\hline Artikel $1.4 \mathrm{~b}$ & $\begin{array}{l}\text { Geïmporteerd oud-papier mag niet mee worden geteld. Aangezien Nederland netto oud- } \\
\text { papier importeert moet hiervoor een correctie plaatsvinden. (Gebeurt al in huidige } \\
\text { Nederlandse berekeningswijze) }\end{array}$ \\
\hline Artikel 1.5 a & $\begin{array}{l}\text { Er moet gecorrigeerd worden voor de gemiddelde toename in het vochtgehalte van oud- } \\
\text { papier en karton. (Gebeurt al in huidige Nederlandse berekeningswijze) }\end{array}$ \\
\hline Artikel $1.5 \mathrm{~b}$ & $\begin{array}{l}\text { Er moet gecorrigeerd worden voor het aandeel niet-verpakkingsmateriaal. (Gebeurt al in } \\
\text { huidige Nederlandse berekeningswijze) }\end{array}$ \\
\hline Artikel 1.7.6 quater $1 . f$ & $\begin{array}{l}\text { Materiaal dat niet afkomstig is van verpakkingen, zoals afval van hetzelfde materiaal dat } \\
\text { samen met het verpakkingsmateriaal is ingezameld en residuen van producten die zich in de } \\
\text { gebruikte verpakking bevonden, mag niet meegerekend worden bij de hoeveelheid } \\
\text { gerecycled verpakkingsafval. (Gebeurt al in huidige Nederlandse berekeningswijze) }\end{array}$ \\
\hline
\end{tabular}

Dit betekent dat in de huidige Nederlandse berekeningsmethode voor het recyclingpercentage alle vermelde correcties worden toegepast en het recyclingpercentage dus niet gaat veranderen.

Gesorteerde producten gemaakt van oud-papier en karton moeten voldoen aan de eisen die gesteld zijn in de norm EN 643. Het maximaal toegestane gehalte aan productvreemde vervuiling in gesorteerde papier en kartonproducten is 1,5\%. Ingezameld papier en karton dat direct zonder sortering wordt gebruikt als grondstof voor een papierrecycler is afkomstig van inzamelgebieden met weinig productvreemde vervuiling. Dit ingezamelde materiaal moet aan dezelfde norm 643 voldoen om te mogen worden geaccepteerd voor recycling.

De sorteerverliezen van Nederlands oud-papier en karton zijn niet openbaar gerapporteerd. Uit gesprekken met vertegenwoordigers van papier-sorteerbedrijven kan worden afgeleid dat het grootste verlies wordt veroorzaakt door kleine papieren objecten als kassabonnetjes, labels, etc. en een kleiner deel van het massaverlies wordt veroorzaakt door het afscheiden van product-vreemde verontreinigingen (kunststof, metaal, glas, textiel, etc.) en vervuilde objecten van papier \& karton (pizzadozen met levensmiddelenresten, etc.). Wel zijn er twee wetenschappelijke artikelen gevonden over het sorteren van papier \& karton. In een Europees artikel uit 2010 wordt gemeld dat er gewerkt wordt aan de ontwikkeling van een automatische sorteertechniek voor papier \& karton met een sorteerverlies van minder dan 5\% [Bobu et al., 2010]. In een internationaal overzichtsartikel worden de sorteerverliezen van enkele sorteermachines besproken, die variëren tussen de 5 en de $20 \%$ [Rahman et al., 2013]. Omdat in machinale sorteerinstallaties doorgaans meerdere sorteermachines zullen worden gebruikt en vaak ook menselijke nacontrole, zullen de feitelijke verliezen lager zijn. Op basis van deze beperkte bronnen schatten wij het sorteerverlies van Nederlands oud-papier en karton in op $5 \pm 3 \%$. 


\subsection{Huidige berekeningswijze}

De berekening van het recyclingpercentage voor papier \& kartonnen verpakkingen in 2017 met de huidige rekenregels, gebeurt volgens vergelijking 1 waarbij het brutogewicht aan gerecycled materiaal de som is van de gescheiden ingezamelde verpakkingen van papier en karton en van het gewicht aan teruggewonnen verpakkingen van papier \& karton. De benodigde gegevens heeft Afvalfonds Verpakkingen voor 2017 verzameld [Afvalfonds 2018]:

- $\quad$ Gewicht op de markt gebracht $=1262$ kton papier \& karton verpakkingen

- $\quad$ Gewicht gescheiden ingezameld = 1220 kton papier \& karton verpakkingen

- $\quad$ Gewicht teruggewonnen (via nascheiding) en gesorteerd $=8$ kton papier $\&$ karton verpakkingen (drankenkartons)

Samen geeft dat 1228 kton papier en karton verpakkingen die na correctie voor het toegenomen vochtgehalte en de netto-import van oud-papier geeft dat:

- $\quad$ Gewicht gerecyclede papier \& karton verpakkingen = 1095 kton

- Dus het recyclingpercentage volgende de huidige definitie is $1095 / 1262=87 \%$

\subsection{Nieuwe berekeningswijze}

Voor de berekening van het recyclingpercentage volgens de nieuwe rekenregels hoeven er verder geen aanvullende correcties te worden verricht. De berekening blijft gelijk aan de hier bovenstaande. Het recyclingpercentage volgens de nieuwe rekenregels voor Nederland in 2017 bedraagt dus nog steeds $87 \%$.

\subsection{Aanvullende opmerking}

Volledigheidshalve wordt opgemerkt dat bij de nieuwe berekeningswijze zoals beschreven in EU 2019/665 niet alle verliezen die optreden bij de recycling van papier en karton worden meegenomen. Zo zijn twee welbekende afvalstromen bij de recycling van papier \& karton nietjesslib en papierslib. Het nietjesslib komt voort uit product-eigen verontreinigingen als nietjes, paperclips etc. De meeste metalen verpakkingscomponenten van papieren- en kartonnen artikelen komen voor bij nietverpakkingen, maar er zijn ook transportdozen met metalen krammen in de zij-naad en dus is het ook relevant voor verpakkingen. Het papierslib vindt zijn oorsprong in onder andere ketendegradatie van meermalig gerecyclede papiervezels. Uit de definitie van het meetpunt in bijlage II van het uitvoeringsbesluit EU 2019/665 volgt dat deze verliezen niet afgetrokken hoeven te worden, omdat deze verliezen optreden tijdens het recyclingproces en het meetpunt uitgaat van het gewicht dat een pulphandeling ingebracht wordt. 


\section{Recyclingpercentage voor glazen verpakkingen}

Bij de inzamel- en recyclingketen van verpakkingsglas is een beperkt aantal spelers betrokken. Meerdere inzameldiensten legen namens gemeenten glasbakken en vervoeren de ingezamelde glazen verpakkingen naar een beperkt aantal 'glas-recyclingbedrijven'. De bedrijven in de glasketen die glasscherven naar soort en kleur sorteren heten opmerkelijk genoeg geen sorteerbedrijven maar recyclingbedrijven, dit in tegenstelling tot bedrijven in de kunststof- en papierketen die vergelijkbare activiteiten uitvoeren ${ }^{4}$. Een klein aantal glasrecyclingbedrijven verwerkt het in Nederland ingezamelde verpakkingsglas, waarvan één bedrijf (Maltha) verreweg het grootste is met een geschat marktaandeel van $75 \%$. Dat maakt deze recyclingketen overzichtelijk. Deze recyclingbedrijven sorteren de scherven en verwijderen ongewenste materialen en zoveel mogelijk scherven van nietverpakkingsglas. De meeste recyclingbedrijven sorteren verpakkingsglasscherven en verhandelen die aan glasovens. Van het Nederlandse verpakkingsglas gaat het overgrote deel $(>80 \%)$ van de scherven terug naar verpakkingsglas en isolatiemateriaal en de rest naar minder-veeleisende toepassingen als polijst en slijpmiddel, schuimglas en bouwmateriaal. Voor de productie van nieuw verpakkingsglas wordt grofweg $40 \%$ gerecyclede glasscherven gebruikt [Wiel van de, 2015]. Het is de ambitie van de glasindustrie om dit percentage verder te verhogen richting de $60 \%$. Dit is eenvoudiger te verwezenlijken voor groene flessen, waarvoor meer dan $85 \%$ recycled content nu al mogelijk is, in vergelijking met bijvoorbeeld transparante potten, waarvoor de kleur-sorteereisen veel hoger liggen en $60 \%$ lastiger te verwezenlijken is [Wiel van de, 2015].

De specificaties waaronder glasscherven worden verkocht aan glasovens hebben zeer lage concentratielimieten voor stoorstoffen als keien, steen en porselein (maximaal $20 \mathrm{~g}$ per ton) en ook voor niet-verpakkingsglassoorten als kristalglas (loodhoudend), thermisch glas (zirkoon-houdend) en laboratoriumglas (boor-houdend).

De glas-recyclingbedrijven hebben gescheiden ingezameld verpakkingsglas en soms ook vlakglas en autoglas als grondstof en maken daarvan meerdere glas-scherven-producten voor de glasovens van verpakkingsglas, een aantal bijproducten voor polijstmiddel- en isolatiemiddelproducenten, bijproducten voor de bouw, metaalproducten en een aantal afvalstromen.

Naast de monitoringsrapportage van Afvalfonds Verpakkingen [Afvalfonds 2018], een rapportage naar het vervuilingsgehalte van gescheiden ingezameld verpakkingsglas [Bureau Milieu en Werk, 2015], een statistische analyse van de inzamelrespons in Nederland [Nedvang 2015] en enkele websites van betrokkenen [http://www.maltha.nl/nl-nl, https://www.grl.be/nl/, https://www.nedvang.nl/recyclingnederland/glas/] en belangenorganisaties [www,duurzaamglas.nl, www.feve.org] is er weinig openbare informatie beschikbaar over de glas-inzamel- en recyclingketen. Ook de wetenschappelijke literatuur is beperkt. Er is een artikel over de invloed van beleid op de Zwitserse glasrecycling [Meylan et al., 2013]. Bovendien zijn er enkele artikelen uit Portugal over de efficiëntie van gescheiden inzameling [Martinho et al., 2017; Oliveira et al., 2017] en over het nascheiden van verpakkingsglas uit gemengd huishoudelijk restafval [Dias et al., 2012; Dias et al., 2015].

Enkele typerende aspecten van de verpakkingsglas inzamel- en recyclingketen zijn:

- Klein aantal spelers, overzichtelijk.

- Huishoudelijk verpakkingsglas wordt of kleurgescheiden (wit, groen, bont) of bont ingezameld.

- Nagenoeg al het huishoudelijk verpakkingsglas wordt via brengbakken ingezameld.

- Bedrijfsmatig verpakkingsglas (vooral horeca) wordt ook gescheiden ingezameld.

- De meest gangbare bierflessen worden ingezameld via een statiegeldsysteem, wel wordt er een stijging waargenomen in het aandeel eenmalig bierglas [Eijk van, 2019].

\footnotetext{
${ }^{4}$ De formele reden hiervoor is dat gesorteerde glasscherven een End-of-Life status als grondstof genieten.
} 
- Het gescheiden ingezamelde glas heeft een laag vochtgehalte (rond de $1 \%$ ) en de producteigen materiaalverontreiniging (papieren etiketten, metalen sluitingen, kurken, etc.) zijn goed afscheidbaar.

- Het gemiddelde verontreinigingsniveau met productvreemde verontreinigingen is laag, ongeveer 0,5\% [Bureau Werk \& Milieu, 2015], inclusief product-eigen verontreinigingen komt dat op maximaal 2,5\% [Wiel van de 2015, UMP], maar de kwaliteitseisen die aan gesorteerde glasscherven worden gesteld zijn nog veel lager $(20 \mathrm{~g} / 1000 \mathrm{~kg}=0,002 \%)$, zodat er nog een forse inspanning moet worden verricht om de scherven binnen specificatie te brengen.

- De meerjarige vervuilingsonderzoeken naar het gescheiden ingezamelde verpakkingsglas laten een licht stijgende trend zien. Vooral het gehalte niet-verpakkingsglas neemt toe, alsmede verpakkingsglasvreemde verontreinigingen [Afvalfonds, 2018]. Hierdoor wordt de sorteer-opgave voor glasrecyclingbedrijven steeds uitdagender en ontstaan er in verhouding meer producten die niet meer terug kunnen naar de glasovens [Eijk van, 2019].

- Bij een beperkt aantal nascheiding-installaties wordt een relatief kleine hoeveelheid glas teruggewonnen uit de organisch natte fractie, gereinigd en verkocht.

Ten aanzien van de bierflessen geldt dat dit voor meer dan $80 \%$ herbruikbare verpakkingen in statiegeldsystemen zijn [Nederlandse brouwers, 2019]. Dit bierglas in statiegeldsystemen beïnvloedt de recyclingpercentages op twee wijzen. Ten eerste wordt het vers op de markt gebrachte bierglas in statiegeldsystemen meegeteld bij het gewicht op de markt gebracht verpakkingsglas in een specifiek jaar. Ten tweede wordt bierglas dat uit dit statiegeldsysteem wordt afgedankt na meerdere omlopen ${ }^{5}$ en in gescheiden inzamelsystemen komt via burgers, winkels of bedrijven gewoon meegeteld bij het gewicht ingezameld verpakkingsglas. Het op de markt brengen van bierglas voor statiegeldsystemen kan minder gelijkmatig plaatsvinden dan het afdanken hiervan, waardoor er schommelingen kunnen ontstaan in de jaarlijkse recyclingpercentages voor verpakkingsglas.

De belangrijkste artikelen van het uitvoeringsbesluit [2019/665] die van toepassing zijn op de inzamel- en recyclingketen van glazen verpakkingen, staan in de onderstaande tabel opgesomd. Zie paragraaf 2.2 voor de citaten van deze artikelen.

\section{Tabel 3 Interpretatie van de belangrijkste artikelen in het besluit en de richtlijn voor de} berekeningswijze van het recyclingpercentage van glazen verpakkingen.

$\begin{array}{ll}\text { Artikel van het besluit } \quad \text { Consequentie voor de berekeningswijze } \\ \text { Bijlage II } & \text { Gesorteerd glas dat geen verdere verwerking ondergaat alvorens een glasoven in te gaan of }\end{array}$

Gijlage II Gesorteerd glas dat geen verdere verwerking ondergaat alvorens een glasoven in te gaan of
de productie van filtreermedia, schuurmateriaal, glasvezelisolatiemateriaal en bouwmateriaal van glas.

Artikel 7.6 quater 1.g Geïmporteerd verpakkingsglasafval mag niet worden meegeteld. (Gebeurt nu ook niet in huidige NL berekeningsmethode)

Artikel 7.6 quater 1.e Er moet worden gecorrigeerd voor het opgenomen vochtgehalte tijdens inzamelen en sorteren. (Dit gebeurt in de huidige systematiek niet ten aanzien van de ingezamelde gewichten. In de nieuwe systematiek zou dit moeten gebeuren ten aanzien van het vochtgehalte van de gesorteerde glasproducten. Direct na productie is het vochtgehalte verwaarloosbaar als gevolg van de droogprocessen. Sommige glasrecyclers slaan gesorteerde glasscherven op in de buitenlucht. Hierdoor staat het bloot aan neerslag. Bij deze recyclers bedraagt het gemiddelde vochtgehalte van gesorteerde glasscherven $3 \%$. )

Artikel 7.6 quater 1.f Glazen niet-verpakkingen en productresiduen mogen niet meegeteld worden in het gerecycled gewicht. Deze worden nu nog wel meegenomen in de berekening van het huidige recyclingpercentage, maar zijn gering: in totaal minder dan 2,5\%. Immers dit is de limiet zoals afgesproken in het UMP. In het geval ingezameld glas meer product-vreemde verontreiniging bevat moet dit ingezamelde gewicht hier eerst voor gecorrigeerd worden [UMP 3.0, bijlage 2, kwaliteitseisen glas] (Beide gewichten zijn echter verwaarloosbaar in gesorteerde glasscherven gemaakt van verpakkingsglas. .)

\footnotetext{
${ }^{5}$ Het gemiddeld aantal omlopen van bierflessen ligt volgens de biersector op 20 à 30 [Nederlandse Brouwers, 2019].
} 
Dit betekent voor de berekening van het recyclingpercentage van glazen verpakkingen dat er volgens het nieuwe uitvoeringsbesluit onderscheid moet worden gemaakt tussen de verschillende producten die uit het gescheiden ingezamelde verpakkingsglas worden gemaakt. Allereerst moet worden nagegaan welke producten zich kwalificeren als recycling en welke als nuttige toepassing. Vervolgens moet voor elk recyclingproduct de hoeveelheid en de zuiverheid in termen van verpakkingsglas bepaald worden. Het rendement van de glasrecycling-stap volgt dan uit het gesommeerde product van hoeveelheden en zuiverheden voor al die recyclingproducten die ook in Bijlage II van het uitvoeringsbesluit worden genoemd.

Een belangrijke speler in recycling van Nederlands en Belgisch verpakkingsglas heeft ter wille van dit project de massabalans van haar verwerkingsproces gedeeld, zie tabel 4 . Dit is een glasrecyclingproces dat bestaat uit thermisch drogen, het afzuigen van fijngoed, het zeven in vier klassengroottes scherven en het per klassengrootte verder machinaal sorteren van de glasscherven met optische scheiders. Andere glasrecyclingbedrijven hebben andere processen of zijn bijvoorbeeld alleen toegerust op bont-ingezameld glas. Desalniettemin, geeft deze massabalans wel een duidelijk beeld van een gemiddeld glasrecyclingproces en kan ze goed gebruikt worden voor het inschatten van het effect van het verschuiven van het meetmoment op het recyclingpercentage.

Tabel 4 Massabalans van de recycler van Nederlands verpakkingsglas met het grootste marktaandeel.

\begin{tabular}{|c|c|c|c|}
\hline Product / Afvalstroom & $\begin{array}{c}\text { Gewichtsaandeel van de } \\
\text { input, }[\%]\end{array}$ & $\begin{array}{l}\text { Gemiddelde onzuiverheid, } \\
\qquad[\%] *\end{array}$ & Toepassing \\
\hline Glasscherven > $4 \mathrm{~mm}$ & 73,5 & 0,015 & Verpakkingsglas \\
\hline $\begin{array}{l}\text { Fijne glasscherven \& } \\
\text { glaspoeder }\end{array}$ & 11 & 0,150 & $\begin{array}{l}\text { Verpakkingsglas, } \\
\text { Schuimglas, Glaswol, } \\
\text { Zandstraalmiddel }\end{array}$ \\
\hline Brandbaar afval (b) & 1,5 & $\sim 100 \%$ & Geen. Afvalverbrandingsoven \\
\hline KSP-uitstoot (c) & 8,2 & $8-11$ & Nuttige toepassingen \\
\hline Metalen (Ferro \& non-ferro) & 1 & $\sim 100 \%$ & Metaalrecycling \\
\hline Vocht & 1 & $\sim 100 \%$ & Verlies van aangehecht vocht \\
\hline
\end{tabular}

*: onzuiverheid is hier gedefinieerd als de som van alles wat geen verpakkingsglas is.

a: bestaat voor het grootste deel uit gedroogd organisch materiaal en heel fijn glaspoeder

b: voornamelijk papier en kunststof

c: Bijproduct waarin niet-verpakkingsglas, keien, steen en porselein worden geconcentreerd, bestaat voor $89-92 \%$ uit glas en voor de rest uit mineraal materiaal en kunststof

Van al deze producten uit het proces van glas-recycling zijn er twee hoofdproducten met verpakkingsglas (glasscherven $>4 \mathrm{~mm}$, fijne glasscherven \& glaspoeder) die sowieso voldoen aan de criteria van bijlage II van het uitvoeringsbesluit, aangezien ze naar verpakkingsglasovens worden afgevoerd. Ook het fijne stof uit het droogproces voldoet aan de beschrijving in bijlage II van het uitvoeringsbesluit, het wordt immers toegepast bij de productie van een bouwmateriaal. Het bijproduct Keramiek, steen en porselein (KSP)-uitstoot wordt toegepast als afdekmateriaal. Een afdekmateriaal is geen bouwmateriaal en kan worden beschouwd als een opvulmateriaal, zoals beschreven in de kaderrichtlijn afvalstoffen en in sectie B.10 van het Landelijk afvalbeheersplan-3 [LAP-3]. Daarmee kwalificeert de toepassing van afdekmateriaal zich als een nuttige toepassing en niet als een vorm van recycling.

Bovenstaande gaat over het gescheiden ingezamelde verpakkingsglas. Daarnaast is er nagescheiden verpakkingsglas dat wordt toegepast als een niet vormgegeven IBC bouwstof in de wegenbouw. Daarmee voldoet deze toepassing aan de definitie van 'recycling' in de kaderrichtlijn afvalstoffen en ook aan de beschrijving van 'recycling' die in bijlage II van het uitvoeringsbesluit.

Opgemerkt moet worden dat de interpretatie of een glasproduct wel of niet aangemerkt kan worden als 'recycling' lastig is. De definities van recycling staan in de Europese kaderrichtlijn afvalstoffen en het Nederlandse LAP-3. Deze definities zijn echter voor meerdere uitleg vatbaar als het om verpakkingsglas-bijproducten en nagescheiden IBC bouwstof gaat, zie ook paragraven 4.2 en 4.3. De 
kern van het verschil tussen 'recycling' en 'nuttige toepassing' voor deze verpakkingsglas-houdende producten zit hem er in of de toepassing als een vorm van 'opvulling' kan worden opgevat. Dat is grotendeels een kwestie van interpretatie en deze interpretatie kan in de toekomst veranderen.

\subsection{Huidige berekeningswijze}

De berekening van het recyclingpercentage voor 2017 met de toen geldende rekenregels en met de gegevens die Stichting Afvalfonds Verpakkingen verzameld heeft [Afvalfonds 2018], verloopt volgens vergelijking 2 . Formeel heet dit een recyclingpercentage, maar specifiek voor verpakkingsglas zou de term inzamelrendement beter op zijn plaats zijn geweest. Kort samengevat waren de door Afvalfonds Verpakkingen verzamelde gegevens:

- Het gewicht op de Nederlandse markt gebrachte glazen verpakkingen in 2017 was 500 kton ( $\mathrm{M}_{\text {markt}}$ )

- Het brutogewicht aan in Nederland gescheiden ingezameld verpakkingsglas bedroeg 420 kton in 2017 ( $\left.M_{\text {ges inz }}\right)$

- Het gewicht aan nagescheiden verpakkingsglas dat als IBC bouwmateriaal in de wegenbouw wordt toegepast bedroeg 10 kton in 2017 (M

Uit vergelijking 2 volgt dat het recyclingpercentage voor verpakkingsglas in Nederland in $201786 \%$ bedroeg.

$$
R_{m}=\frac{M_{\text {ges inz }}+M_{\text {bouwmateriaal }}}{M_{\text {markt }}}=\frac{420+10}{500}=86 \%
$$

Vergelijking 2: Berekening van het recyclingpercentage voor Nederlands verpakkingsglas in 2017 volgens de toenmalige rekenregels.

\subsection{Nieuwe berekeningswijze}

Het recyclingpercentage voor Nederlands verpakkingsglas in 2017 volgens de nieuwe rekenregels verloopt volgens vergelijking 3 .

$$
R_{m}=\frac{\sum_{i} M_{\text {product } i} \times c_{\text {product } i}^{\text {verpakkingsglas }}+M_{\text {bouwmateriaal }}}{M_{\text {markt }}}
$$

\section{Vergelijking 3: Berekening van het recyclingpercentage voor Nederlands verpakkingsglas in} 2017 volgens het nieuwe uitvoeringsbes/uit.

Om deze berekening te kunnen uitvoeren zijn voor alle producten (i) die verpakkingsglas bevatten en voldoen aan de beschrijving zoals gesteld in bijlage II van het uitvoeringsbesluit de volgende parameters noodzakelijk:

- $M_{\text {product } \mathrm{i}}$ : het totale gewicht aan sorteerproduct i dat verpakkingsglas bevat.

- $\quad c_{\text {product } i}^{\text {verpakingslas }}$ : de concentratie aan verpakkingsglas in sorteerproduct i.

- Mbouwmateriaal: Gewicht aan verpakkingsglas in nagescheiden bouwmateriaal.

De hoeveelheden van producten die uit het gescheiden ingezamelde verpakkingsglas gemaakt kunnen worden, kunnen worden berekend door de totale bruto-hoeveelheid gescheiden ingezameld verpakkingsglas (420 kton) te vermenigvuldigen met de massabalans-gegevens in tabel 4 . Ook de concentraties aan verpakkingsglas in deze sorteer-producten staan in tabel 4 gemeld. Deze correcties met de concentraties verpakkingsglas in de glasproducten is noodzakelijk omdat de bruto-hoeveelheid gescheiden ingezameld verpakkingsglas volgens de monitoringsrapportage nog niet gecorrigeerd is voor de aanwezigheid van productvreemde vervuiling (lees: niet-verpakkingsglas en andere materialen). 
Het gewicht aan nagescheiden verpakkingsglas in IBC bouwmateriaal was 10 kton in 2017. De berekening van het gemiddelde recyclingpercentage volgens de nieuwe berekeningswijze is hieronder verduidelijkt.

$$
R_{m}=\frac{420 \times[0,735 \times 0,99985+0,11 \times 0.9985+0,038 \times 0.95]+10}{500}
$$

De berekende totale hoeveelheid producten gemaakt uit verpakkingsglas die voldoen aan de beschrijving in bijlage II van het uitvoeringsbesluit komt daarmee op ongeveer 380 kton voor Nederland in 2017. Zodoende is het recyclingpercentage, berekend volgens de nieuwe rekenregels, voor Nederlands verpakkingsglas in $201776 \%$.

Deze berekening wordt sterk bepaald door wat wel en wat niet als recycling kan worden beschouwd. In het geval in de toekomst deze interpretatie strenger wordt gedaan en IBC bouwstof en verwerken van verpakkingsglas in bakstenen niet meer als recycling gelden, dan daalt het recyclingpercentage naar $71 \%$. Uitgaande van de gerapporteerde $86 \%$ in 2017 kent het effect van de nieuwe meetmethode daardoor de volgende spreiding: tussen $71 \%$ en $76 \%$.

De onzekerheid rond de toekomstige interpretatie van het begrip 'recycling' heeft een grote invloed op de einduitkomst in het recyclingpercentage van verpakkingsglas. Bepaalde glas-bijproducten die nu niet als recycling tellen, zouden in de toekomst met een meer ruimhartige interpretatie mogelijk wel meegeteld kunnen worden. Wanneer de toepassing van KSP-uitstoot wel als recycling zou worden beschouwd, dan zou het recyclingpercentage nog kunnen stijgen tot $82 \%$.

Deze onzekerheid is naar verwachting groter dan de spreiding in scheidingsprestaties tussen glasrecyclingbedrijven onderling.

Overigens hoeft er in deze berekening niet te worden gecorrigeerd voor het toegenomen vochtgehalte na sorteren, omdat de berekening niet op feitelijke gewichten maar op een massabalans is gebaseerd.

\subsection{Aanbeveling}

Uit de Europese kaderrichtlijn afvalstoffen kan niet eenduidig worden afgeleid welke bijproducten uit de glasrecycling formeel kunnen worden beschouwd als 'recycling' zoals bedoeld artikel 3.17 van de kaderrichtlijn. Evenmin kan worden eenduidig worden afgeleid of dit voldoet als 'recycling van het oorspronkelijke functionele materiaal in een niet gelijke of vergelijkbare toepassing' zoals beschreven in deeldocument B.9 van het LAP-3. Hetzelfde geldt voor verpakkingsglas in de nagescheiden inerte fractie die momenteel als IBC bouwstof wordt toegepast. De discussie over recyclingpercentages is gebaat bij duidelijk hieromtrent. Zodoende bevelen wij aan de Europese en Nederlandse overheid aan om hier duidelijkheid over te scheppen. 


\section{Verkenning van de berekening van het recyclingpercentage voor metalen verpakkingen}

De inzamel- en recyclingketen van metalen verpakkingen is om meerdere redenen ingewikkeld. Ten eerste zijn er twee soorten metalen verpakkingen, de stalen verpakkingen (Ferrometalen genoemd) en de aluminium verpakkingen (ingedeeld bij de non-ferrometalen). Ten tweede zijn veel verschillende categorieën: de huishoudelijke metalen verpakkingen, de bedrijfsmatige metalen verpakkingen en metalen logistieke hulpmiddelen (drums, frames voor intermediate bulkcontainers, gascilinders, glasbokken etc.). Daarnaast zijn er meerdere inzamelsystemen; via de oud-ijzer-handel, via het restafval en de bodemassen, via het PMD, via nascheiding en via het Klein Chemisch Afval (KCA, bv. de verfblikken). Bovendien zijn er in de meeste metaalstromen zowel verpakkingen als nietverpakkingen aanwezig. Verder kennen zuivere metaalstromen een relatief hoge financiële waarde. Dit vergroot de belangen van de betrokkenen, beperkt de transparantie van de verwerkingsketens en verlaagt de kans dat metaalstromen uitvallen.

Een positief punt is dat er van de recyclingketens van aluminium-verpakkingen veel internationale wetenschappelijke literatuur beschikbaar is [Graedel et al. 2011, Hu et al. 2011, Biganzoli \& Grosso 2013, Rahman \& Bakker 2013, Biganzoli et al 2014, Allegrini et al. 2014, Gijlswijk \& Ansems 2014, Warrings \& Fellner 2018, Van Caneghem et al. 2019]. Een overzichtsartikel maakt duidelijk dat de recyclingketens in verschillende EU lidstaten totaal anders zijn vormgegeven. In sommige landen domineren statiegeldsystemen, in andere gescheiden inzamelsystemen en in weer andere de terugwinning uit bodemassen. Bovendien blijkt dat het recyclingpercentage in landen met dezelfde dominante inzamel- of terugwinningsystemen totaal verschillend kan zijn [Warrings \& Fellner, 2019]. Toch is de betekenis van deze literatuur beperkt voor de Nederlandse situatie, aangezien de terugwinningspercentages voor metalen uit Nederlands bodemas relatief hoog zijn [Gijlswijk \& Ansems 2014, Afvalfonds 2018] ten opzichte van die uit bodemas in andere Europese landen [Van Caneghem et al. 2019]. Dit wordt toegeschreven aan de inzet van veel innovatieve technologieën in de bodemasopwerking in Nederland.

Nederland heeft altijd meerdere inzamelsystemen gehad voor metaalverpakkingen. Voor 2014 verliep de recycling hoofdzakelijk via de terugwinning uit bodemassen, KCA, oud-metaalhandel en blikbakken. Vanaf 2010 kwam nascheiding in Nederland op en vanaf 2015 de PMD inzameling, terwijl blikbakken nagenoeg verdwenen zijn. Er zijn nu zeker zeven inzamel- en terugwinning-systemen:

1. Oud-ijzer-handel,

2. KCA-inzameling,

3. Gescheiden inzameling bij milieustraten,

4. Gescheiden inzameling bij bedrijven,

5. Terugwinning uit bodemassen van afvalverbrandingsinstallaties,

6. Terugwinnen van metalen middels nascheiding uit restafval,

7. PMD-inzameling.

Om het recyclingpercentage van de metaalverpakkingen te kunnen berekenen, zouden er dus veertien inzamel- en recyclingketens moeten worden beschreven ( 7 ketens voor 2 metaalsoorten). Een aantal van die ketens zijn echter nog nooit technisch onafhankelijk doorgemeten en beschreven in openbare rapporten en publicaties. Een mogelijke oplossing hiervoor zou kunnen zijn dat de ketens waarvoor wel gegevens beschikbaar zijn in detail worden beschreven en doorgerekend en dat voor de andere ketens vereenvoudigingen of veronderstellingen worden toegepast. Deze aanpak is gevolgd in de huidige Nederlandse berekeningswijze (paragraaf 2.1). Uit de tekst van het Europese uitvoeringsbesluit kan niet worden opgemaakt of deze aanpak hiermee in overeenstemming is. 
Zodoende is het met de huidige kennis niet mogelijk om een recyclingpercentage volgens de nieuwe berekeningswijze te becijferen, maar kan er wel een overzicht worden gemaakt van wat wel en wat niet bekend is en wat dus nog bepaald moet gaan worden alvorens het verwachte nieuwe recyclingpercentage berekend kan gaan worden. Dat overzicht wordt in dit hoofdstuk gegeven.

De belangrijkste artikelen van het toepassingsbesluit [2019/665] die van toepassing zijn op de inzamel- en recyclingketen van metalen verpakkingen zijn in tabel 5 samengevat. Zie paragraaf 2.2 voor de citaten van deze artikelen.

\section{Tabel 5: Interpretatie van de belangrijkste artikelen in het besluit voor de} berekeningswijze van het recyclingpercentage van metalen verpakkingen.

\begin{tabular}{|c|c|}
\hline $\begin{array}{l}\text { Artikel van het } \\
\text { besluit }\end{array}$ & Consequentie voor de berekeningswijze \\
\hline Bijlage II & $\begin{array}{l}\text { Het nieuwe meetpunt is gesorteerd metaal dat geen verdere verwerking ondergaat alvorens een } \\
\text { smelterij of oven in te gaan. }\end{array}$ \\
\hline Bijlage III & Berekeningswijze voor het recyclingpercentage van metaalverpakkingen uit bodemassen \\
\hline Artikel 7.6 quater $1 . e$ & $\begin{array}{l}\text { Er moet worden gecorrigeerd voor het opgenomen vochtgehalte tijdens inzamelen en sorteren. } \\
\text { (Dit kan relevant zijn voor gesorteerd metaal uit PMD en nascheiding) }\end{array}$ \\
\hline Artikel 7.6 quater $1 . f$ & $\begin{array}{l}\text { Metalen niet-verpakkingen en productresiduen mogen niet meegeteld worden in het gerecycled } \\
\text { gewicht. (Dit kan relevant zijn voor gesorteerd metaal uit PMD en nascheiding) }\end{array}$ \\
\hline Artikel 7.6 quater $1 . \mathrm{g}$ & $\begin{array}{l}\text { Correctie voor internationale handel van afvalstromen die metaalverpakkingen bevatten. } \\
\text { Aangezien er in Nederland veel buitenlands afval wordt verbrand is dit vooral voor uit } \\
\text { bodemassen teruggewonnen metalen relevant. }\end{array}$ \\
\hline
\end{tabular}

\subsection{Huidige berekeningswijze}

De huidige berekeningswijze is beschreven in het uitvoerings- en monitoringsprotocol voor metaalverpakkingen [UMP], zie ook paragraaf 2.1. In het monitoringsrapport van Afvalfonds Verpakkingen voor 2017 staan enkele belangrijke parameters [Afvalfonds, 2018]. Zo is er in 2017 in totaal 216 kton metalen verpakkingen op de markt gebracht. Er is geen uitsplitsing in stalen en aluminium-verpakkingen beschikbaar. Wel is een totaal-uitsplitsing naar oorsprong beschikbaar: 119 kton metalen verpakkingen van bovendrempelige bedrijven (producenten en importeurs van verpakte producten die individueel meer dan $50.000 \mathrm{~kg}$ verpakkingen op de Nederlandse markt brengen), 3 kton metalen verpakkingen van onderdrempelige bedrijven (bedrijven die minder dan $50.000 \mathrm{~kg}$ verpakkingen op de Nederlandse markt brengen) en 94 kton logistieke hulpmiddelen.

Afvalfonds Verpakkingen rapporteert dat het totale gewicht aan gerecyclede metaalverpakkingen in 2017205 kton bedraagt. Uit de tekst kan worden opgemaakt dat dit gewicht gerecyclede metaalverpakkingen is opgebouwd uit verschillende bijdragen van logistieke hulpmiddelen, van terugwinning uit bodemassen, gescheiden inzameling, KCA etc. maar de precieze bijdragen tot dit gerecyclede gewicht zijn niet vermeld. Het recyclingpercentage komt daarmee uit op 95\%. Verder veronderstelt het Afvalfonds Verpakkingen dat het recyclen van metalen uit de PMD inzameling met een vergelijkbaar rendement plaatsvindt als dat van de metalen in het restafval die uit de bodemassen worden teruggewonnen.

Vast staat dat er aanzienlijke hoeveelheden metaal in Nederland worden gerecycled [Rijkswaterstaat 2018b]. Ook duidelijk is dat de huidige berekeningswijze door de Inspectie Leefomgeving en Transport voor 2015 is getoetst en dat zij er geen inhoudelijke opmerkingen over had, uitsluitend enkele algemene aanbevelingen [ILT 2017]. Desalniettemin is de huidige berekeningswijze niet inzichtelijk en is deze dus niet door onafhankelijke wetenschappers te onderzoeken. Omdat de onderliggende gegevens en de toekenningswijzen niet openbaar zijn, is het onmogelijk om het recyclingpercentage onder de regels van het nieuwe uitvoeringsbesluit 2019/665/EG te berekenen. 


\subsection{Benodigde gegevens voor het berekenen van het nieuwe recyclingpercentage}

Per recyclingroute zal nagegaan worden welke parameters er nodig zijn om een recyclingpercentage te berekenen. Bij elke route zullen Ferrometalen en non-ferro-metalen worden besproken.

\subsubsection{Oud-metaalhandel}

De Nederlandse oud-metaalhandel bestaat uit tientallen bedrijven die metalen inzamelen en verder verhandelen. Vaak handelen ze in alle metalen, zowel ijzer, staal als aluminium, maar ook brons, koper, lood, zink etc. De Metaalrecyclingfederatie (www.mrf.nl) vertegenwoordigt deze branche. Ze registreert de totale hoeveelheden ingezameld metaal per soort van haar leden, maar niet naar de aard van de ingezamelde objecten (verpakkingen of niet-verpakkingen).

In de huidige berekeningswijze wordt verondersteld dat middels de oud-metaalhandel $99 \%$ van de logistieke hulpmiddelen worden ingezameld, na opvolging van een advies dat volgde uit de ILT controle, omdat deze een duidelijke waarde vertegenwoordigen en verlies dus onwaarschijnlijk is. Uit de tekst van het nieuwe Europese uitvoeringsbesluit 2019/665 kan niet worden opgemaakt dat deze veronderstelling niet mag worden gedaan.

\subsubsection{Klein chemisch afval}

Met het klein chemisch afval worden verfblikken, spuitbussen en batterijen ingezameld en verwerkt. Dit wordt gesorteerd en naar gespecialiseerde verwerkers gestuurd. Voor verpakkingen zijn in het bijzonder verfblikken en spuitbussen relevant. Deze zullen worden gereinigd door middel van verbranding en uit de assen zullen metalen worden teruggewonnen.

De hoeveelheid klein chemisch afval wordt nationaal geregistreerd en gemonitord en bedroeg 22 kton in 2018 [CBS statline website]. Uit het monitoringsprotocol blijkt dat RWS jaarlijks de samenstelling van het KCA bepaalt, dat verfblikken de metaalverpakkingen in KCA domineren en dat de fractie metalen verfblikken in KCA wordt gebruikt om de hoeveelheid hieruit gerecyclede metaalverpakkingen te berekenen. Wel blijkt volgens het ILT rapport dat er 6 kton metaalverpakkingen in het KCA waren in 2015 [ILT 2017].

Aangezien de actuele hoeveelheid met KCA ingezamelde metalen verfblikken niet openbaar is, alsmede de nu uitgevoerde berekeningswijze om hieruit het gerecyclede gewicht te berekenen, kan niet worden vastgesteld of deze berekening in overeenstemming is met het nieuwe uitvoeringsbesluit, in het bijzonder met bijlage III van dit uitvoeringsbesluit, waar specifiek wordt ingegaan op de berekeningswijze van recyclingpercentages van metaalverpakkingen die een verbrandingsstap hebben ondergaan.

\subsubsection{Gescheiden ingezamelde metaalverpakkingen}

Metaalverpakkingen worden zowel bij bedrijven als bij gemeenten (milieustraten) gescheiden ingezameld. De hoeveelheid gescheiden ingezamelde metaalverpakkingen bij bedrijven wordt momenteel niet geregistreerd, maar wel uit productiegegevens ingeschat. De hoeveelheid gescheiden ingezamelde metaalverpakkingen bij gemeenten wordt wel geregistreerd via Wastetool (het digitale systeem waarmee gemeenten de ingezamelde hoeveelheden verpakkingsmaterialen registreren bij Nedvang). Uit beide hoeveelheden kunnen de gerecyclede hoeveelheden worden berekend door te corrigeren voor de verliezen die bij de metaalrecycler optreden en het vochtgehalte. Hiervoor is dan wel aanvullend technisch onderzoek nodig om zowel de samenstellingen van deze afvalstromen te bepalen als de gemiddelde technische verliezen die bij de recycling hiervan optreden. 


\subsubsection{Bodemas-verwerking van afvalverbrandingsinstallaties}

In het uitvoeringsbesluit is bijlage III opgenomen waarin staat uitgelegd welke parameters bekend moeten zijn om het recyclingpercentage via de bodemas-route te berekenen, zie ook paragraaf 2.2. Deze parameters worden hieronder achtereenvolgens besproken.

\section{$\mathbf{m}_{\text {total IBA }} \quad$ [kton/jaar]}

De totale massa aan bodemassen afkomstig uit afvalverbrandingsinstallaties die uit Nederland afkomstig huishoudelijk en bedrijfsmatig restafval verbranden per jaar is onbekend. In de jaarlijkse WAR rapportage staat de hoeveelheid bodemassen die in Nederlandse afvalverbrandingsinstallaties worden geproduceerd [Rijkswaterstaat 2018b], dit is echter niet hetzelfde omdat er restafval wordt geïmporteerd en geëxporteerd. Ook de hoeveelheden Nederlands restafval (huishoudelijk en bedrijfsmatig) die in Nederland worden verbrand en de hoeveelheid geïmporteerd restafval wordt gerapporteerd in de WAR rapportage. De hoeveelheden die geëxporteerd worden staan helaas niet gerapporteerd, evenmin de metaalconcentraties van deze verschillende soorten restafval, zodat de gewenste massa ook niet met grote betrouwbaarheid berekend kan worden.

\subsubsection{Bodemas-route Ferrometalen}

\section{$\mathbf{m}_{\text {total IBA Fe [kton/jaar] }}$}

Totale massa aan Ferrometalen in bodemassen afkomstig uit afvalverbrandingsinstallaties die uit Nederland afkomstig huishoudelijk en bedrijfsmatig restafval verbranden per jaar.

Volgens bijlage III en vergelijking III-1 van het uitvoeringsbesluit moet deze totale massa aan Ferrometalen in de bodemassen worden afgeleid uit het product van de massa aan teruggewonnen Ferro-concentraten uit deze bodemassen ( $\left.m_{\text {total IBA Fe concentrates }}\right)$ vermenigvuldigd met de concentratie aan Ferrometalen in deze concentraten ( $\mathrm{C}_{\mathrm{IBA} F \mathrm{Fe}}$ ). De eerste term moet worden opgevraagd bij de scheidingsinstallaties. De concentratie zal moeten volgen uit regelmatig uitgevoerde metingen. Beide termen zijn nu onbekend.

Overigens wordt de hoeveelheid Ferrometaal in bodemassen van Nederlandse afvalverbrandingsinstallaties wel gerapporteerd [RWS 2018b], maar is dit door de import en export van afval niet

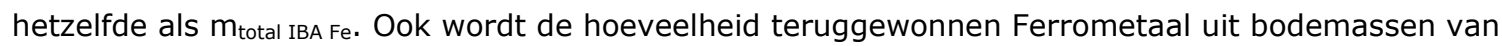
Nederlandse afvalverbrandingsinstallaties gerapporteerd in het kader van de Green deal bodemassen. Deze rapportage is echter niet openbaar.

\section{CiBA Fe. [\%]}

De concentratie van Ferrometalen in het teruggewonnen Ferrometaal-concentraat moet volgens bijlage III van het uitvoeringsbesluit worden bepaald uit regelmatig uitgevoerde metingen en vergelijking 2. Deze metingen zijn -zover ons bekend- nog niet uitgevoerd en dus zijn de resultaten daarvan nu niet beschikbaar.

\section{$\mathbf{m}_{\text {PW IBA Fe [kton/jaar] }}$}

De totale massa aan Ferrometalen in bodemassen afkomstig van Ferrometaal-verpakkingen en uit Afvalverbrandingsinstallaties die uit Nederland afkomstig huishoudelijk en bedrijfsmatig restafval verbranden per jaar wordt berekend met vergelijking 4 van bijlage III van het uitvoeringsbesluit. Hiertoe wordt $m_{\text {total IBA Fe }}$ gecorrigeerd voor de aanwezigheid van Ferrometaal-niet-verpakkingen in het te verbranden restafval. Dit moet worden gedaan door de gewichten aan Ferrometaal-verpakkingen in het te verbranden restafval ( $\mathrm{m}_{\mathrm{PW}} \mathrm{Fe}$ ) regelmatig te bepalen, alsmede de gewichten aan alle Ferrometaal-objecten in het te verbranden restafval $\left(m_{\mathrm{W} \mathrm{Fe}}\right)$ en $\mathrm{m}_{\text {total IBA Fe }}$ te corrigeren met de onderlinge verhouding. Deze metingen zijn zover ons bekend niet gedaan. Er zijn in ieder geval geen openbare meetresultaten over beschikbaar en dus kan deze berekening nu niet worden gedaan op de wijze zoals beschreven in het uitvoeringsbesluit. 


\subsubsection{Bodemas-route non-ferrometalen}

Voor de non-ferrometalen die teruggewonnen worden uit de bodemassen geldt grotendeels hetzelfde als voor de Ferrometalen, namelijk dat de meetgegevens die het uitvoeringsbesluit vereist, niet beschikbaar zijn en dat er dus hooguit een inschatting kan worden gemaakt. Daar bovenop zijn er twee verschillen. Ten eerste, de factor $r_{\mathrm{Al}}$ (concentratie aluminium in het non-ferro-metaalconcentraat) moet meegenomen worden in de berekening van de concentratie. Ten tweede, het non-ferrometaalconcentraat dat uit bodemassen wordt teruggewonnen ondergaat nog aanvullende behandelingen alvorens het aan een smelterij wordt verkocht om als grondstof te worden ingevoerd. Toch zijn voor deze nabehandelingen geen verdere correcties nodig omdat de berekeningswijze hierin al voorziet.

\section{$\mathbf{m}_{\text {total IBA Al [kton/jaar] }}$}

Totale massa aan aluminium in bodemassen afkomstig uit afvalverbrandingsinstallaties die uit Nederland afkomstig huishoudelijk en bedrijfsmatig restafval verbranden per jaar.

Volgens bijlage III en vergelijking III-1 van het uitvoeringsbesluit moet deze totale massa aan aluminium in de bodemassen worden afgeleid uit het product van de massa aan teruggewonnen nonferro-concentraten uit deze bodemassen ( $m_{\text {total IBA } n \text { Fe concentrates }}$ ) vermenigvuldigd met de concentratie aan aluminium in deze concentraten ( $\mathrm{C}_{\mathrm{IBA} A \mathrm{AI}}$ ). De eerste term moet worden opgevraagd bij de scheidingsinstallaties. De concentratie zal moeten volgen uit regelmatig uitgevoerde metingen. Beide termen zijn nu onbekend. Wel worden naar verluid deze metingen uitgevoerd in het kader van de Green deal bodemassen, maar zijn de gegevens daarvan nu niet openbaar.

\section{Ciba Al. [\%]}

De aluminium-concentratie in het teruggewonnen non-ferrometaal-concentraat moet volgens bijlage III van het uitvoeringsbesluit worden bepaald uit regelmatig uitgevoerde metingen en vergelijking 3. Deze metingen zijn nog niet uitgevoerd en dus zijn de resultaten daarvan nu niet beschikbaar.

\section{m}

De totale massa aan aluminium in bodemassen afkomstig van aluminium-verpakkingen en uit afvalverbrandingsinstallaties die uit Nederland afkomstig huishoudelijk en bedrijfsmatig restafval verbranden per jaar wordt berekend met vergelijking 4 van bijlage III van het uitvoeringsbesluit. Hiertoe wordt $m_{\text {total IBA Al }}$ gecorrigeerd voor de aanwezigheid van aluminium-niet-verpakkingen in het te verbranden restafval. Dit moet worden gedaan door de gewichten aan aluminium-verpakkingen in het te verbranden restafval ( $\mathrm{m}_{\mathrm{PW} \text { Al }}$ ) regelmatig te bepalen, alsmede de gewichten aan alle aluminiumobjecten in het te verbranden restafval $\left(m_{W}\right.$ Al $)$ en $m_{\text {total IBA Al }}$ te corrigeren met de onderlinge verhouding. Deze metingen zijn echter niet gedaan en dus kan deze berekening nu niet worden gedaan op de wijze zoals de EU commissie die heeft bedoeld.

Het non-ferrometaal-concentraat dat is teruggewonnen uit de bodemassen van afvalverbrandingsinstallaties zal verhandeld worden aan bedrijven die het verder opwerken tot een aluminium-product (bv. Liquisort te Son en Pyral te Freiberg), wat vervolgens weer verhandeld wordt aan smelterijen. Uiteraard treden hierbij materiaalverliezen op, die echter niet verder meegerekend te hoeven worden. In de berekeningswijze in bijlage III van het uitvoeringsbesluit is hier immers al voor gecorrigeerd.

\subsubsection{PMD route metalen}

De hoeveelheid Ferrometaal-verpakkingen die via de PMD-inzamelroute wordt gerecycled ( $\mathrm{m}_{\mathrm{PW}} \mathrm{PMD}$ Fe) kan in de toekomst worden berekend met de navolgende parameters:

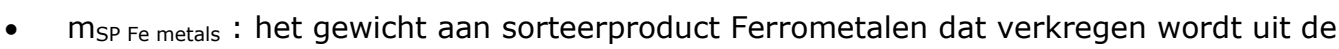
sortering van PMD, [kton].

- $\quad \mathrm{CPW}_{\mathrm{PE} \text { SP }}$ : de concentratie aan Ferrometaal-verpakkingen in het sorteerproduct "Ferrometalen" verkregen uit de sortering van PMD, [\%].

- $\quad$ RPY: Het opwerkrendement van Ferrometaal-verpakkingen uit het sorteerproduct tot een concentraat dat aan ovens of smelterijen kan worden verkocht, [\%]

- $M C$ : Het vochtgehalte in dit concentraat, [\%] 
Volgens de onderstaande vergelijking.

$$
m_{P W P M D F e}=m_{S P \text { Fe metals }} \times c_{P W F e ~ S P} \times R P Y \times(100 \%-M C)
$$

Aangezien het totaalgewicht aan geproduceerd sorteerproduct "Ferrometalen" uit PMD formeel niet bekend is, kan deze berekening niet worden uitgevoerd.

Voor aluminium-verpakkingen die via de PMD-inzamelroute worden gerecycled geldt dezelfde vergelijking maar dan met aangepaste parameters voor het gewicht aan sorteerproduct nonferrometalen, de concentratie aan aluminium-verpakkingen in het sorteerproduct "non-ferrometalen", het opwerkrendement van aluminium-verpakkingen uit het sorteerproduct tot een concentraat dat aan smelterijen kan worden verkocht en het vochtgehalte van dit concentraat.

\subsubsection{Nascheiding-route metalen}

Een beperkt aantal nascheiding-bedrijven produceert ook metaal-concentraten uit het bij hen ingevoerde restafval, bij andere nascheiding-installaties gebeurt dat niet. Uit het monitoringsprotocol blijkt dat deze hoeveelheden nu al meegerekend worden met het gewicht gerecyclede metaalverpakkingen. De wijze waarop die berekening nu plaatsvindt is niet uit het monitoringprotocol te herleiden, zodat ook geen oordeel kan worden gevormd of de huidige berekeningswijze al dan niet voldoet aan de eisen van het nieuwe uitvoeringsbesluit. Zodoende volgt hieronder een algemene berekeningswijze waarmee met zekerheid kan worden voldaan aan deze eisen van het uitvoeringsbesluit.

De hoeveelheid Ferrometaal verpakkingen die via de nascheiding-route wordt gerecycled ( $\mathrm{m}_{\mathrm{PW}} \mathrm{MR}$ Fe) kan in de toekomst worden berekend met dezelfde soort parameters als voor de PMD-route:

- $\quad M_{R}$ Fe metals : het gewicht aan nascheiding-product Ferrometalen dat verkregen wordt uit ingaand Nederlands restafval, [kton].

- $\quad \mathrm{C}_{\mathrm{PW} F \mathrm{R}}$ : de concentratie aan Ferrometaal-verpakkingen in het nascheiding-product "Ferrometalen", [\%].

- RPY: Het opwerkrendement van Ferrometaal-verpakkingen uit het nascheiding-product tot een concentraat dat aan ovens of smelterijen kan worden verkocht, [\%]

- MC: Het vochtgehalte in dit concentraat, [\%]

Volgens de onderstaande vergelijking.

$$
m_{P W M R F e}=m_{R \text { Fe metals }} \times c_{P W F e R} \times R P Y \times(100 \%-M C)
$$

De hoeveelheid aluminium-verpakkingen die via de nascheiding-route wordt gerecycled kan op vergelijkbare wijze worden ingeschat.

\subsection{Berekening van nieuwe recyclingpercentages voor metaalverpakkingen}

In de toekomst kan het nieuwe recyclingpercentage voor Ferrometaal-verpakkingen worden berekend met de onderstaande formule:

$$
R Y_{F e P W}=\frac{m_{P W F e M T}+m_{P W F e K C A}+m_{P W F e C W}+m_{P W F e R C}+m_{P W I B A F e}+m_{P W P M D F e}+m_{P W M R F e}}{m_{F e \text { metal packaging on the market }}}
$$

Deze termen zijn nu nog niet bekend, zodat er dus ook nog geen recyclingpercentage kan worden berekend. Op gelijke wijze kan er in de toekomst ook een nieuw recyclingpercentage voor aluminiumverpakkingen worden berekend. 
Het mag duidelijk zijn dat het nu niet mogelijk is om een inschatting te maken van het recyclingpercentage voor metalen verpakkingen volgens de regels in het nieuwe uitvoeringsbesluit. Om inzichtelijk te maken welke inspanningen er nodig zijn om dit in de toekomst wel te kunnen, volgt in tabel 6 een opsomming van wat er in de toekomst zal moeten worden geregistreerd en gemeten. Een aantal gegevens zijn al bekend bij betrokkenen, maar veel gegevens zullen gemeten en bepaald moeten worden, dit is in de tabel aangegeven. Dit zal een forse inspanning vergen. Het is voor te stellen dat de Raamovereenkomstpartijen ervoor gaan kiezen om veronderstellingen te doen en om daarmee de berekeningswijze te vereenvoudigen. De monitoringswijze is echter geen onderdeel van deze studie.

Tenslotte moet opgemerkt worden dat ondanks het feit dat er nog veel technische parameters of nu nog niet openbaar zijn of nog niet gemeten zijn, het recyclingpercentage voor metalen verpakkingen hoog zal uitpakken. Immers de totale hoeveelheden metalen die uit de bodemassen van afvalverbrandingsinstallaties worden teruggewonnen en openbaar gerapporteerd worden in de WAR rapportage zijn hoog (103 kton Ferro-metaal en 29 kton non-Ferro-metaal) [Rijkswaterstaat 2018b]. Ook groot is de hoeveelheid logistieke hulpmiddelen (94 kton op de markt) waarvan mag worden uitgegaan dat die ingezameld en gerecycled worden. Zodat ondanks alle onzekerheden het recyclingpercentage voor metaalverpakkingen wel hoog zal moeten zijn. 


\section{Tabel 6 Opsomming van de gegevens die nodig zijn om recyclingpercentages voor metalen verpakkingen te berekenen volgens het nieuwe uitvoeringsbes/uit.}

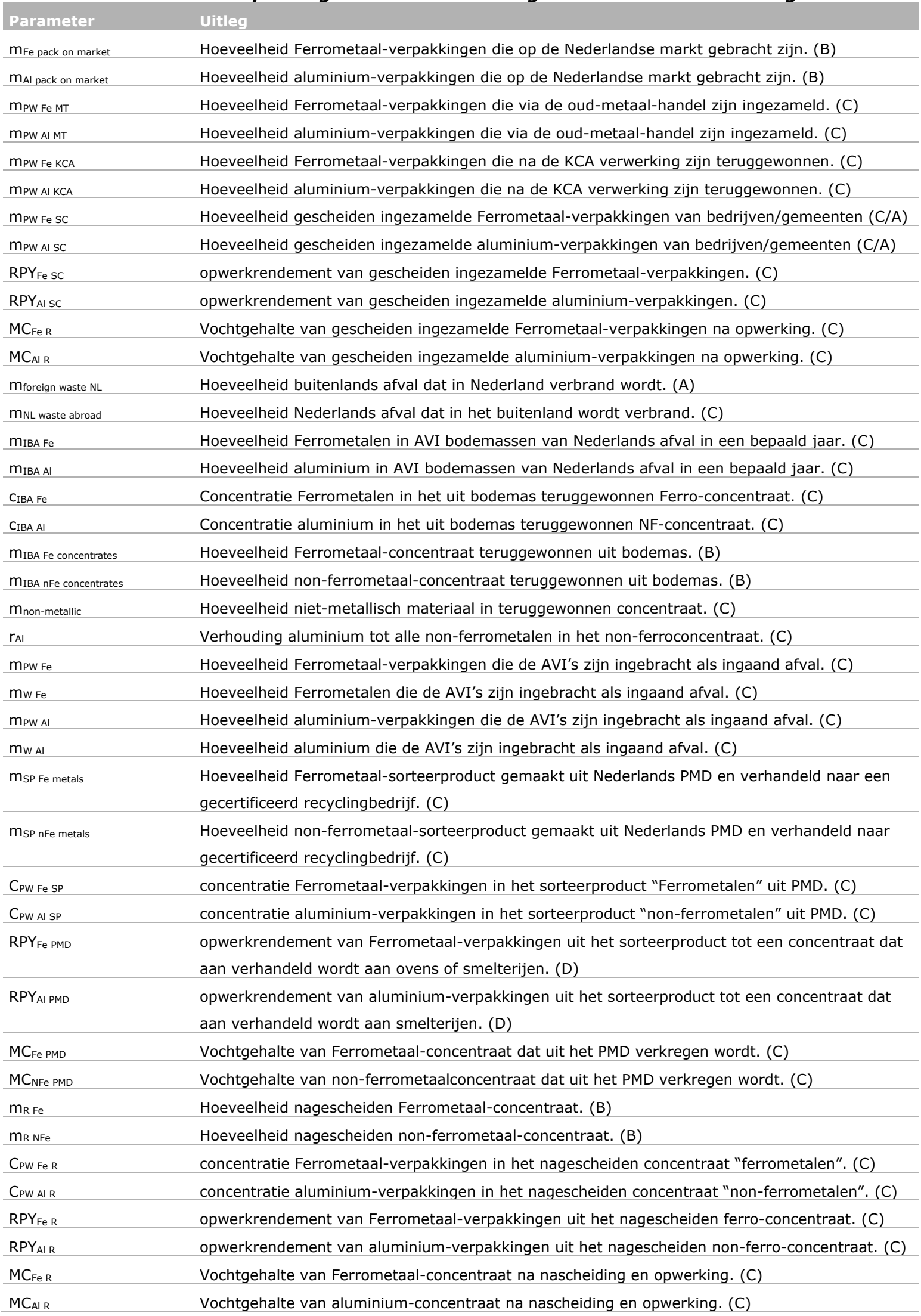

A: Beschikbare en openbare gegevens die voldoen aan de eisen van het uitvoeringsbesluit EU 2019/665.

B: Beschikbare, maar nu nog vertrouwelijke gegevens die waarschijnlijk voldoen aan het uitvoeringsbesluit.

C: Data niet beschikbaar op de wijze zoals het uitvoeringsbesluit die voorschrijft, wel kan er een indicatieve inschatting worden gegeven.

D: Data die nog volledig onbekend is. 


\section{Algemene opmerkingen over de recycling van houten verpakkingen}

Een analyse van het verwachte recyclingpercentage voor houten verpakkingen behoort niet tot de opdracht. Wel is gevraagd om een uitspraak te doen wat het effect is van het nieuwe uitvoeringsbesluit op het overall recyclingpercentage voor verpakkingen. Daarmee is het relevant om een globale inschatting te geven van het effect van het uitvoeringsbesluit op het recyclingpercentage voor hout.

Bij houten verpakkingen domineren de logistieke hulpmiddelen, zoals pallets en kisten [Afvalfonds 2018]. Dergelijke verpakkingen bestaan hoofdzakelijk uit hout en kennen in verhouding weinig verpakkingseigen-vreemd-materialen als spijkers, metalen hoekstukken, nietjes, kunststofblokken en foliestukken. Een groot deel van deze houten transportverpakkingen zitten in statiegeldpools, worden meerdere keren in omloop gebracht en worden zo mogelijk gerepareerd. Lastig punt voor deze verpakkingen is de internationale handel, waardoor er veel uitwisseling is.

Houten verpakkingen die niet meer kunnen worden gerepareerd, worden in Nederland voornamelijk afgevoerd naar recyclingbedrijven. Zij versplinteren en vermalen deze houten verpakkingen en maken hieruit spaanplaat, underlayment, MDF, pallet-klossen, zaagsel als bodembedekking voor kooidieren, etc. Deze recyclingbedrijven accepteren alleen sorteerproducten van houten verpakkingen als het gehalte aan vreemd-materiaal (metaal, kunststof) onder de $1 \%$ ligt. $^{6}$

Gegeven het feit dat er sowieso weinig vreemd-materialen in houten verpakkingen aanwezig zijn en dat de sorteereis streng is (maximaal $1 \%$ ), is het plausibel dat het recyclingpercentage berekend volgens de regels van het nieuwe uitvoeringsbesluit weinig minder zal zijn dan het huidige recyclingpercentage.

\footnotetext{
${ }^{6}$ Op basis van informatie van Afvalfonds Verpakkingen en Stichting Kringloop Hout.
} 


\section{Overall recyclingpercentage}

In dit rapport is inzicht gegeven in het te verwachten recyclingpercentage voor verpakkingen van glas en oud papier \& karton volgens de nieuwe Europese regelgeving. In een eerder rapport [Brouwer et al., 2019] is het recyclingpercentage al berekend voor kunststof verpakkingen. In hoofdstuk 5 is aangegeven waarom het nieuwe recyclingpercentage voor metalen verpakkingen nog niet kan worden berekend, maar dat dit naar alle waarschijnlijkheid wel hoog zal zijn. In hoofdstuk 6 is voor houten verpakkingen aangegeven dat het plausibel is dat ook voor deze verpakkingen het huidige recyclingpercentage waarschijnlijk weinig zal verminderen onder het nieuwe uitvoeringsbesluit. Door de informatie van alle verschillende materialen te combineren, kan een indicatie gegeven worden van het te verwachten recyclingpercentage met de nieuwe meetmethode voor alle verpakkingen. Voor metalen en houten verpakkingen is dus geen berekening gedaan, maar alleen een globale inschatting gedaan dat beide weinig zullen veranderen onder invloed van het nieuwe uitvoeringsbesluit. Daarom is voor de bepaling van het overall recyclingpercentage voor alle verpakkingen aangenomen dat de percentages voor hout en metaal niet wijzigen met de nieuwe meetmethode. We verwachten echter dat deze wel iets dalen, maar op dit moment kan niet ingeschat worden hoeveel dit zal zijn. Dit betekent dus dat het overall recyclingpercentage zoals hieronder berekend is, een overschatting is en in werkelijkheid iets lager zal komen te liggen. Onze voorzichtige inschatting is dat dit overall recyclingpercentage dan met ongeveer $1 \%$ zal dalen.

Het huidige recyclingpercentage ligt voor 2017 voor alle Nederlandse verpakkingen op 78\% [Afvalfonds, 2018]. De inschatting is dat dit met de nieuwe meetmethode daalt naar 74 à $75 \%$. Dit is dus een overschatting en het getal zal in werkelijkheid lager komen te liggen. Een overzicht van alle getallen per materiaal staat in tabel 7 .

Tabel 7 Recyclingpercentages voor 2017 zoals gerapporteerd door Afvalfonds Verpakkingen en die berekend zijn volgens de nieuwe berekeningswijze.

\begin{tabular}{lll} 
Materiaal & Recyclingpercentage 2017 & Ingeschat recycling percentage \\
Glas & [Afvalfonds, 2018] & nieuwe meetmethode \\
& $86 \%$ & $71-76 \%$ (mogelijk $82 \%$ wanneer KSP \\
Papier en karton & & uitstoot ook meegenomen mag worden) \\
\hline Kunststof & $87 \%$ & $87 \%$ \\
\hline Metaal & $50 \%$ & $35-39 \%$ \\
\hline Hout & $95 \%$ & $95 \% !$ \\
\hline Totaal recycling & $\mathbf{7 3 \%}$ & $\mathbf{7 3 \% !}$ \\
\hline
\end{tabular}

!: onder de aanvechtbare, maar niet vermijdbare, veronderstelling dat het recyclingpercentage constant blijft voor die materialen waarvoor geen nieuw recyclingpercentage berekend kon worden. 


\section{Literatuur}

Afvalfonds. 2018. Monitoring verpakkingen, resultaten inzameling en recycling 2017.

Allegrini E, Maresca A, Olsson ME, Sommer Holtze M, Boldrin A, Astrup TF. 2014. Quantification of the resource recovery potential of municipal solid waste incineration bottom ashes. Waste Manage. 34, 1627-1636.

Biganzoli L, Grosso M. 2013. Aluminium recovery form waste incineration bottom ash and its oxidation level. Waste manage. Res. 31, 954-959.

Biganzoli L, Grosso M, Forte F. 2014. Aluminium mass balance in waste incineration and recovery potential from the bottom ash: a case study. Waste Biomass Valor. 5, 139-145.

Bobu E, Iosip A, Ciolacu F. 2010. Potential benefits of recovered paper sorting by advanced technology. Cellulose Chem. Techn. 44, 461- 471.

Brouwer MT, Smeding IW, Thoden van Velzen EU, 2019. Verkenning effect verschuiven meetpunt recycling kunststofverpakkingen, WFBR report 1923, maart 2019, https://doi.org/10.18174/474139/

Bureau Milieu en Werk. 2014. Vervuilingsonderzoek glas 2014 in opdracht van Nedvang. Tilburg.

Caneghem van J, Coster de E, Vandenbergh K, Broyer de S, Lambrix N, Weemaels M. 2019. Closing the household metal packaging cycle through recovery of scrap from waste-to-energy bottom ash: The case study of Flanders. Resour. Conserv Recycl. 144, 115-122.

CBS statline website: https://opendata.cbs.nl/statline/\#/CBS/nl/, bezocht 4 juli 2019.

Dias N, Carvalho MT, Pina P. 2012. Minerals Engineering. Characterization of Mechanical Biological Treatment reject aiming at packaging glass recovery for recycling. 29, 72-76.

Dias N, Garrinhas I, Maximo A, Belo N, Roque P, Carvalho MT. 2015. Recovery of glass from the inert fraction refused by MBT plants in a pilot plant. Waste Manage. 46, 201-211.

Europees Parlement, 1994, Raad van de Europese Unie, Richtlijn 94/62/EG van het Europees Parlement en de Raad van 20 december 1994 betreffende verpakking en verpakkingsafval, ELI: http://data.europa.eu/eli/dir/1994/62/oj

Europese Commissie, 2005, Beschikking 2005/270/EC van de commissie van 22 maart 2005 tot vaststelling van de tabellen voor het databanksysteem overeenkomstig Richtlijn 94/62/EG van het Europees Parlement en de Raad betreffende verpakking en verpakkingsafval, ELI: http://data.europa.eu/eli/dec/2005/270/oj

Europees Parlement, 2008, Raad van de Europese Unie, Richtlijn 2008/98/EG van het Europees Parlement en de Raad van 19 november 2008 betreffende afvalstoffen en intrekking van een aantal richtlijnen. http://data.europa.eu/eli/dir/2008/98/oj

Europees Parlement, 2018, Richtlijn (EU) 2018/852 van het Europees Parlement en de Raad van 30 mei 2018 tot wijziging van Richtlijn 94/62/EG betreffende verpakking en verpakkingsafval, ELI: http://data.europa.eu/eli/dir/2018/852/oj

Europese Commissie, 2019, Uitvoeringsbesluit (EU) 2019/665 van de commissie van 17 april 2019 tot wijziging van Beschikking 2005/270/EG tot vaststelling van de verslagleggingsmodellen voor het databanksysteem overeenkomstig Richtlijn 94/62/EG van het Europees Parlement en de Raad betreffende verpakking en verpakkingsafval, ELI: http://data.europa.eu/eli/dec_impl/2019/665/oj

Eijk van A. 2019. Glasfabrieken schroeven zuiverheidseisen op, glasinzameling focust op kwantiteit en niet op kwaliteit. Vereniging Afvalbedrijven, 28 juni 2019, https://www.verenigingafvalbedrijven.nl/nieuws/glasfabrieken-schroeven-zuiverheidseisen-op

Ewijk van S, Stegemann JA, Ekins P. 2018. Global Life Cycle Paper Flows, Recycling Metrics, and Material Efficiency. Journal of Industrial Ecology. 22, 686-693. DOI: 10.1111/jiec.12613.

Graedel TE, Allwood J, Birat JP, Buchert M, Hagelüken C, Reck BK, Sibley SF, Sonnemann G. 2011. What do we know about metal recycling rates? J. Ind. Ecol. 15, 355-366.

Gijlswijk van RN, Ansems AMM. 2014. Resultaten massabalans ferro en aluminium bij de verwerking van bodemassen 2014. TNO, Utrecht, R11178.

Hoogland, Y. 2015. Productvreemde vervuiling in huishoudelijk papier. PRN, Hoofddorp 2015.

Hu Y, Bakker MCM, Heij PG. 2011. Recovery and distribution of incinerated aluminium packaging waste. Waste Manage. 31, 2422-2430. 
Inspectie Leefomgeving en Transport. 2017. Toezicht recyclenormen Besluit beheer verpakkingen, onderdeel papieren en metalen verpakkingen 2015. Utrecht.

LAP-3, Landelijk Afvalbeheersplan 3. Eerste wijziging van 19 juli 2019, Zie: https://lap3.nl/ , In het bijzonder de deeldocumenten B.9 Recycling, B.10 Andere nuttige toepassing en Sectorplan 41 Verpakkingen algemeen zijn van toepassing.

Meylan G, Seidl R, Spoerri A. 2013. Transitions of municipal solid waste management, part I: Scenarios of Swiss waste glass-packaging disposal. Resour. Conserv. Recycl. 74, 8-19.

Martinho G, Gomes A, Santos P, Ramos M, Cardoso J, Silveira A, Pires A. 2017. A case study of packaging waste collection systems in Portugal - Part I: Performance and operation analysis. Waste manage. 61, 96-107.

Nederlandse Brouwers. 2019. https://www.nederlandsebrouwers.nl/biersector/duurzaamheid-enketenbeheer/verpakkingen/ (bezocht op 29 augustus 2109).

Nedvang. 2015. Statistisch onderzoek glas inzameling, relatie tussen glasinzameling, gemeente-, glasbak- en huishoudelijke kenmerken. Nedvang Rotterdam. 2015. p 71.

Oliveira V, Sousa V, Vaz JM, Dias-Ferreira C. 2017. Model for the separate collection of packaging waste in Portuguese low-performing recycling regions. J Environ Manag. 216, 13-24.

PRN. 2017. Resultaten monitoring inzameling en recycling niet-verpakkingstoepassingen van papier en karton 2017. Hoofddorp.

Rahman A, Bakker MCM. 2013. Sensor based control in eddy current separation of incinerator bottom ash. Waste Manage. 33, 1418-1424.

Rahman MA, Hussain A, Basri H. 2013. Critical review on waste paper sorting techniques. Int. J. Environ. Sci. Techn. 11, 551-564.

Regeling formulier verslaglegging verpakkingen van 31 mei 2014, nr. IENM/BSK-2014/112494, https://wetten.overheid.nl/BWBR0035143/2014-05-31 .

Rijkswaterstaat. 2017. Samenstelling van het huishoudelijk restafval, sorteeranalyses 2016 ; Gemiddelde driejaarlijkse samenstelling 2015. Rijkswaterstaat - Utrecht. 46 p. ISBN 978-9491750-16-8.

Rijkswaterstaat. 2018a. Verkenning kwaliteit deelstromen gft-afval, papier, glas en textiel uit huishoudens. VANG Huishoudelijk afval. RWS, Utrecht augustus 2018.

Rijkswaterstaat. 2018b. Afvalverwerking in Nederland, gegevens 2017. Werkgroep Afvalregistratie. Utrecht : Rijkswaterstaat, 2018.

Thoden van Velzen EU, Brouwer MT, Augustinus A. 2016. Contributions of municipalities to the recycling of post-consumer packages. Wageningen. WFBR report 1687.

UMP, Uitvoerings- en monitoringprotocol verpakkingen 3.0, http://www.umpverpakkingen.nl/umpverpakkingen, geraadpleegd op 1-3-2019

Warrings R, Fellner J. 2018. Current status of circularity for aluminum from household waste in Austria. Waste Manage. 76, 217-224.

Warrings R, Fellner J. 2019. Management of Aluminium Packaging Waste in selected European countries. Waste Manage. Res. 37, 357-364.

Wiel van der H. 2015. Glas heeft het eeuwige leven. Vereniging Afvalbedrijven, juli 2015, p 5. 



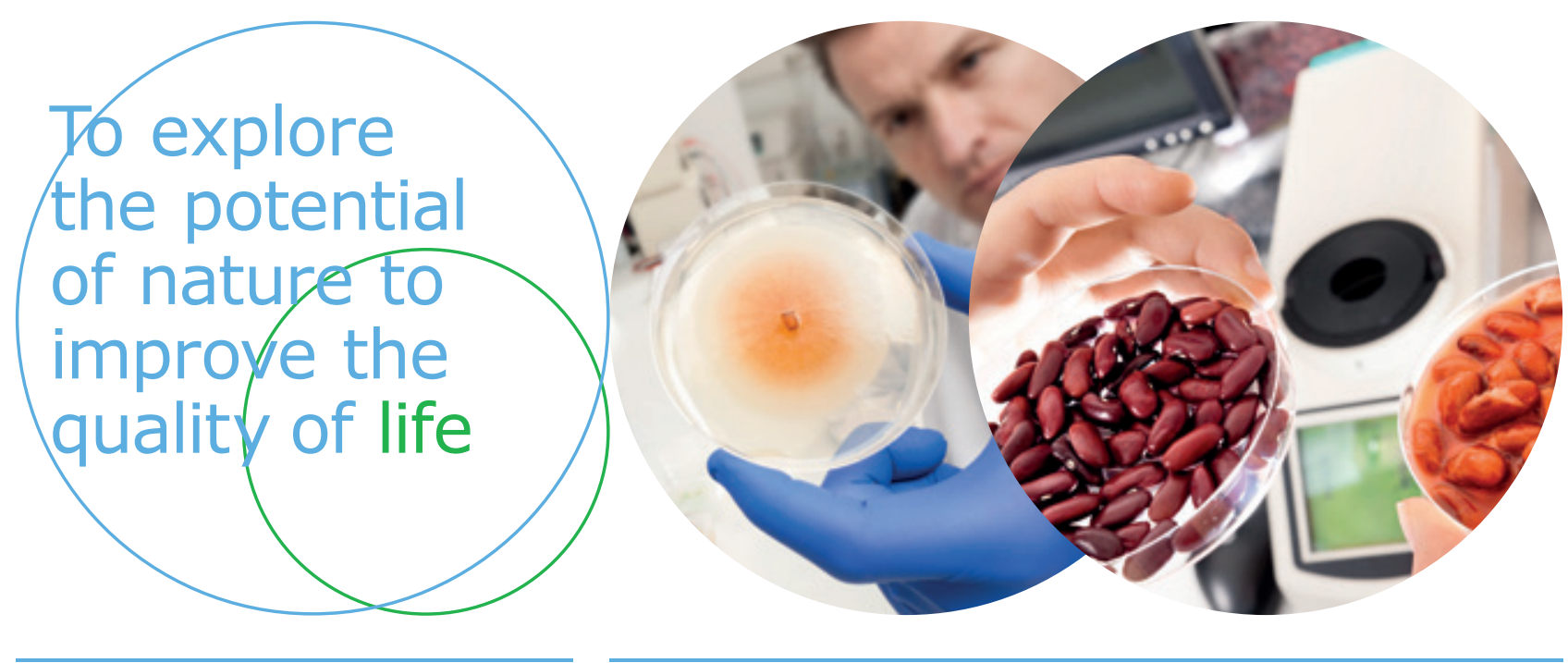

Wageningen Food \& Biobased Research Bornse Weilanden 9

6708 WG Wageningen

www.wur.nl/wfbr

info.wfbr@wur.nl

Rapport 1984

ISBN 978-94-6395-172-2
De missie van Wageningen University \& Research is 'To explore the potential of nature to improve the quality of life'. Binnen Wageningen University \& Research bundelen Wageningen University en gespecialiseerde onderzoeksinstituten van Stichting Wageningen Research hun krachten om bij te dragen aan de oplossing van belangrijke vragen in het domein van gezonde voeding en leefomgeving. Met ongeveer 30 vestigingen, 5.000 medewerkers en 10.000 studenten behoort Wageningen University \& Research wereldwijd tot de aansprekende kennisinstellingen binnen haar domein. De integrale benadering van de vraagstukken en de samenwerking tussen verschillende disciplines vormen het hart van de unieke Wageningen aanpak. 